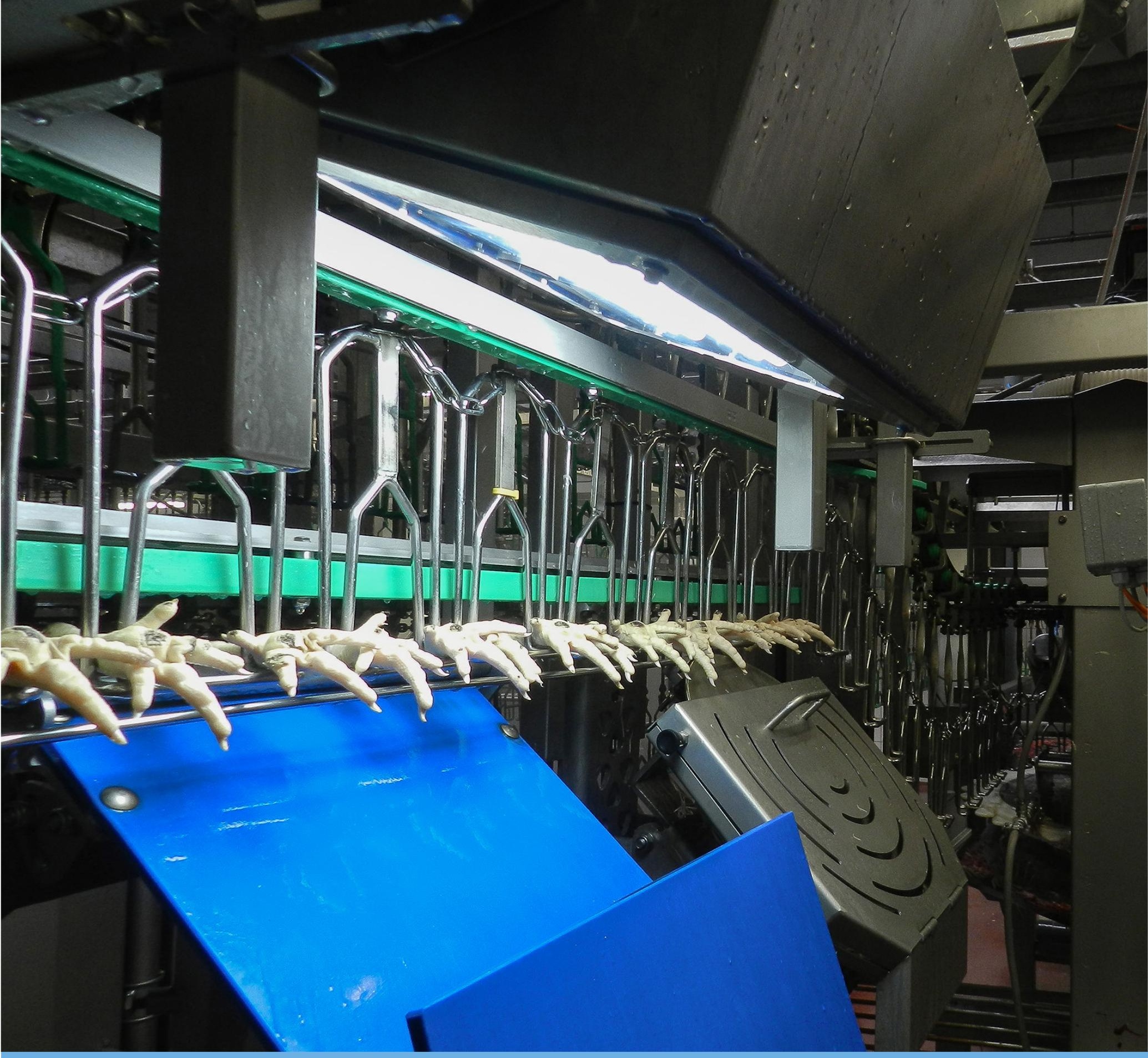

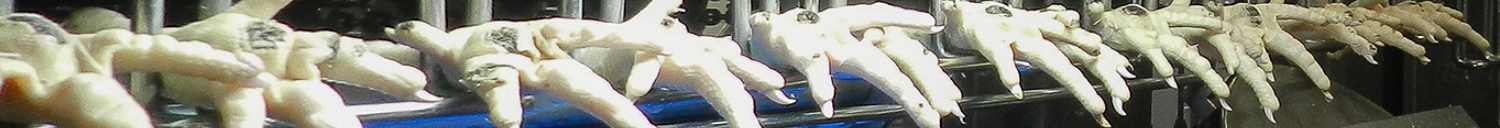

Validation of Meyn Footpad Inspection System 



\section{Validation of Meyn Footpad Inspection System}

J. van Harn ${ }^{1}$ and I.C. de Jong ${ }^{1}$

${ }^{1}$ Wageningen Livestock Research

This research was conducted by Wageningen Livestock Research, commissioned and funded by the Ministry of Economic Affairs, within the framework of Policy Support Research theme

'Animal Welfare' (project number BO-20-008-036).

Wageningen Livestock Research

Wageningen, December 2017

Report 1044B 
Van Harn, J., De Jong, I.C., 2017. Validation Meyn Footpad Inspection System. Wageningen Livestock Research, Report 1044B.

\section{Summary UK}

The current report describes the results of a validation of the Meyn Footpad Inspection System, a video imaging system to score footpad lesions in broiler chickens at the slaughter plant. It was suggested that the system might assign a different score to footpad lesions compared to a trained manual scorer. Therefore, on the request of the Ministry of Economic Affairs, Wageningen Livestock Research performed a limited validation of the system during two days at a commercial plant in The Netherlands. During the validation, the footpad lesion score was determined in a sample of each flock slaughtered on that particular day, manually by a trained observer as well as by the camera system, and the results were compared. This reports describes the results of this validation.

\section{Samenvatting NL}

Dit rapport beschrijft de resultaten van een validatie van het Meyn Footpad Inspection System, een camerasysteem om automatisch voetzoollaesies bij vleeskuikens aan de slachtlijn te beoordelen. $\mathrm{Er}$ gaan geluiden op dat dit camerasysteem mogelijk anders scoort dan handmatige metingen aan de slachtlijn door getrainde slachterijmedewerkers. Op verzoek van het Ministerie van Economische Zaken heeft Wageningen Livestock Research daarom een beperkte validatie van het camerasysteem uitgevoerd. Deze validatie werd uitgevoerd op één Nederlandse slachterij en omvatte twee reguliere slachtdagen. Op deze slachtdagen werd de voetzoollaesiescore van een steekproef van alle aangevoerde koppels zowel handmatig als met de camera bepaald. In dit rapport worden de resultaten van deze metingen beschreven.

This report can be downloaded for free from https://doi.org/10.18174/429581 or www.wur.nl/livestock-research (under Wageningen Livestock Research publications).

\section{(C) 2017 Wageningen Livestock Research}

Postbus 338, 6700 AH Wageningen, T 03174839 53, E info.livestockresearch@wur.nl, www.wur.nl/livestock-research. Wageningen Livestock Research is part of Wageningen University \& Research.

Wageningen Livestock Research accepts no liability for any damage that could arise from the use of the results of this research or from the application of the advice contained therein.

All rights reserved. No part of this publication may be copied and/or published by means of printing, photocopy, microfilm or otherwise without the prior permission of the publisher or author.

ISO 9001 certification by DNV testifies to our level of quality. The General Terms and Conditions of the Animal Sciences Group apply to all of our research projects. These are deposited with the District Court of Zwolle. 


\section{Contents}

$\begin{array}{ll}\text { Preface } & 5\end{array}$

$\begin{array}{ll}\text { Summary } & 7\end{array}$

$\begin{array}{ll}\text { Introduction } & 9\end{array}$

$\begin{array}{lll}1.1 & \text { Objective } & 9\end{array}$

2 Method $r$

$\begin{array}{lll}2.1 & \text { Video-imaging system } & 10\end{array}$

2.2 Collection of feet and images $\quad 12$

2.3 Comparison of camera and manual measurement $\quad 12$

2.4 Data processing 13

2.4.1 Calculation of correlations 13

2.4.2 Statistical analysis 13

2.4.3 Comparison of measurement of both footpads with assessment of $\begin{array}{ll}\text { only the left or right foot } & 14\end{array}$

3 $\begin{array}{ll}\text { Results } & 15\end{array}$

$\begin{array}{lll}3.1 & \text { Video-imaging system performance } & 15\end{array}$

3.2 Comparison per score class 16

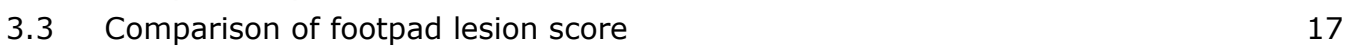

3.4 Comparison between soft and hard scald 18

$\begin{array}{lll}3.5 & \text { Statistical analysis } & 19\end{array}$

3.6 Comparison of measurement of both footpads with assessment of only the left or right foot $\quad 19$

$\begin{array}{lr}\text { Conclusions } & 24\end{array}$

$\begin{array}{ll}\text { Literature } & 25\end{array}$

$\begin{array}{lll}\text { Annex } 1 & \text { Software recipe for soft scald } & 26\end{array}$

$\begin{array}{lll}\text { Annex } 2 & \text { Software recipe for hard scald } & 27\end{array}$

Annex 3 Score card footpad lesions broiler chickens version $1.3 \quad 28$

$\begin{array}{lll}\text { Annex } 4 & \text { Scores per class } & 30\end{array}$

Annex 5 Correlation per scoring class (based on samples) 32

Annex 6 Footpad lesion scores per sample and at flock level 33

$\begin{array}{lll}\text { Annex } 7 & \text { Footpad lesion scores per sample } & 35\end{array}$

Annex $8 \quad$ Examples of images inaccurately measured 36

Annex 9 Correlation per scoring class (based on samples) 38

Annex 10 Correlation footpad lesion score (based on sample test) 40

$\begin{array}{lll}\text { Annex } 11 & \text { Statistical analysis } & 41\end{array}$ 


\section{Preface}

Between 2006 and 2011, Meyn Food Processing Technology developed a video-imaging system in conjunction with Wageningen University \& Research to automatically score footpad lesions at the slaughter line. This system, the Meyn Footpad Inspection System, was until recently used in two poultry slaughterhouses in the Netherlands. However, questions have been raised as to the performance of the video-imaging system. For this reason, Wageningen University \& Research, Livestock Research, at the request of the Ministry of Economic Affairs, has again conducted a limited validation of the video-imaging system similar to the previous validations conducted in 2013 and 2015. This report describes the results of this validation.

Ingrid de Jong (project leader) 


\section{Summary}

Meyn Food Processing Technology has developed a video-imaging system in conjunction with Wageningen Livestock Research to automatically score footpad lesions at the slaughter line. Over the last few years, Meyn has further developed this video-imaging system. However, in practice there are still questions from poultry processors and slaughterhouses as to the accuracy of the camera measurements in comparison with manual measurements performed at the slaughter line (by trained staff, inspectors or veterinarians). For this reason, the Ministry of Economic Affairs again asked Wageningen Livestock Research to conduct a validation of the video-imaging system.

This validation of the video-imaging system took place at a poultry slaughterhouse in the Netherlands. The system had already been in use at this slaughterhouse for a few years. Measurements were done with the video-imaging system on two regular slaughtering days, Monday 20 February 2017 and Monday 15 May 2017, from all flocks slaughtered on those days. On the first day, 7 flocks were slaughtered and measured and on the second, 11 flocks. A flock is defined as all animals from the same broiler house delivered at the same time to the slaughterhouse. One or more samples were taken from each flock. In total this resulted in 35 samples, 20 on the first slaughtering day and 15 on the second day. Per sample, approximately 400 pairs of feet were scored by the video-imaging system and from this series, 100 right feet were manually scored by a trained Wageningen Livestock Research (WLR) inspector. It was not possible to compare manual inspection one-to-one with camera inspection because of the speed of the slaughter line. Footpad lesion scores were compared for both hard and soft scald.

Based on this limited comparison of footpad lesion scores by the Meyn Footpad Inspection System and Wageningen Livestock Research, the scores given by the video-imaging system appear to correlate well with those of the trained WLR inspector, as demonstrated by the high correlation found $\left(R^{2}=0.96\right)$. Flocks with very low footpad lesion scores (FPS (Footpad Score) <60) received a slightly higher score from the video-imaging system than from the WLR inspector and flocks with very high footpad lesion scores (FPS >120) received a slightly lower score from the camera than from the WLR inspector. The difference with the camera was greater with hard scald than with soft scald temperature.

On average across all flocks the video-imaging system gave a slightly higher score (i.e. a worse score) to a flock than the WLR inspector (camera v. WLR 82 vs. 78 points). In two of the eighteen flocks, the footpad lesion score given by the Meyn Footpad Inspection System differed by more than 20 points from that of the WLR inspector. These were all flocks with large but superficial lesions, which were incorrectly assigned a score of 2 by the camera, whilst they should have been classified as class- 1 lesions. In ten of the eighteen flocks, the difference in the footpad lesion score assigned by the videoimaging system and the WLR inspector was lower than 10 points, and in six flocks, the difference was between 10 and 20 points.

In conclusion, based on this limited validation, the score from the Meyn Footpad Inspection System appears to correlate well with the score from the WLR inspector. The camera scored the lesions more severe than the WLR inspector, as a result of which on average the footpad lesion scores from the video-imaging system were slightly higher than those of the WLR inspector. This applied especially to flocks with no to low footpad lesion scores (FPS between 0 and 60). The main advantage of the videoimaging system over a manual assessment is that almost all footpads in a flock are scored. In this very limited validation study the video-imaging system was able to assess the footpads of $99 \%$ of the broiler chickens. In a manual assessment only 100 feet per flock are assessed in accordance with the protocol, irrespective of the size of the flock. The sample (i.e. where in the flock these feet are selected) in a manual measurement can therefore have a major effect on the flock's final footpad lesion score because the extent to which footpad lesions can occur is not always uniformly distributed across a broiler house. 


\section{Introduction}

Since 2013, the Meyn Footpad Inspection System (a video-imaging system for automatically assessing footpad lesions on broiler chickens at the slaughter line) is an approved method for scoring footpad lesions under the EU Broiler Directive (2007/43/EC). Approval for this system was obtained after a limited validation by Wageningen Livestock Research (De Jong, 2013) during which the score of the video-imaging system was compared to the 'gold standard', i.e. a trained inspector from Wageningen Livestock Research, who scored according to a previously established classification system for footpad lesions in broiler chickens.

Although the video-imaging system is an approved method to assess footpad lesions at the slaughter line, the majority of poultry slaughterhouses continue to assess footpad lesions manually in accordance with the established protocol (De Jong et al., 2011). A possible reason for the limited use of the video-imaging system in the Netherlands is its price. However, the poultry industry also raises doubts as to whether the system measures correctly. This is despite the fact that since the validation in 2013 (De Jong, 2013), the video-imaging system has been further improved.

In light of the ongoing debate as to the way in which the video-imaging system measures footpad lesions, but also in light of the advantages of the video-imaging system compared to manual assessment, the Ministry of Economic Affairs asked Wageningen Livestock Research to again conduct a limited validation using the most recent version of the video-imaging system, similar to the limited validation carried out previously (De Jong, 2013).

\section{$1.1 \quad$ Objective}

To establish whether or not the Meyn Footpad Inspection System scores footpad lesions in line with the scoring system used by Wageningen Livestock Research (De Jong et al., 2011). 


\section{Method}

\section{$2.1 \quad$ Video-imaging system}

The validation of the video-imaging system took place at a broiler chicken slaughterhouse in the Netherlands. In this slaughterhouse, the most recent version of the video-imaging system was installed and was already in use for some time. Please refer to De Jong et al., (2011) for a description of the video-imaging system. Figure 2.1 shows the video-imaging system and the positioning system. Figure 2.2 shows the camera as it was installed in the slaughterhouse.

Meyn has updated both the hardware and software of the original validated video-imaging system (De Jong, 2013). These updates were made to further improve the performance of the video-imaging system. They included the addition of a positioning system to better position the feet in the camera's view. This positioning system has ensured in over 95 percent of all feet in a flock being able to be measured. This is much higher than the 70 percent originally required from the video-imaging system (De Jong et al., 2011). In addition, the software was updated so that the camera scores would correlate even better with those of a trained inspector, i.e. the 'gold standard'. Below is a list of all the individual updates, both to hardware and software, made to the video-imaging system since the latest validation in 2015 (De Jong and Van Harn, unpublished data).

Hardware updates:

1. Guide rod added to pick the feet from a guide wheel. Guide wheel to achieve optimal positioning of the feet for proper recognition by the camera.

2. A spray bar with a timer to clean the back panel of dirt such as feathers and skin scales.

Software updates:

1. Software made more robust to improve segmentation.

2. New rule added to better recognise superficial lesions, which are difficult for everyone to recognise, and properly classify them.

3. New rule added to recognise concealed lesions (due to skin folds) on the border of or just within the measurement area and properly classify them.

4. Update to the colour settings to improve detection and recognition of lesions and reduce sensitivity to high relative humidity in the direct surroundings.

5. Update to the software to ignore the new guide rod.

6. In readiness for August/September 2017: automatic recognition of image quality and an alert in case of a decline in quality (for example lime scale on the window). 


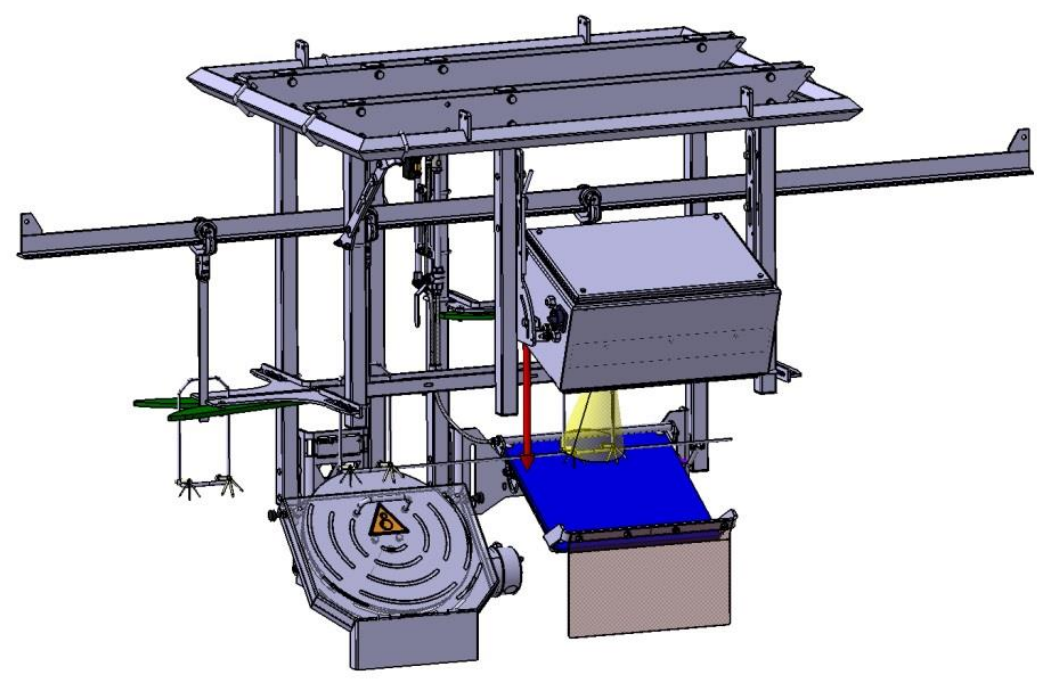

Figure 2.1 Image of the camera set-up including the positioning unit at the slaughter line right in front of the camera.

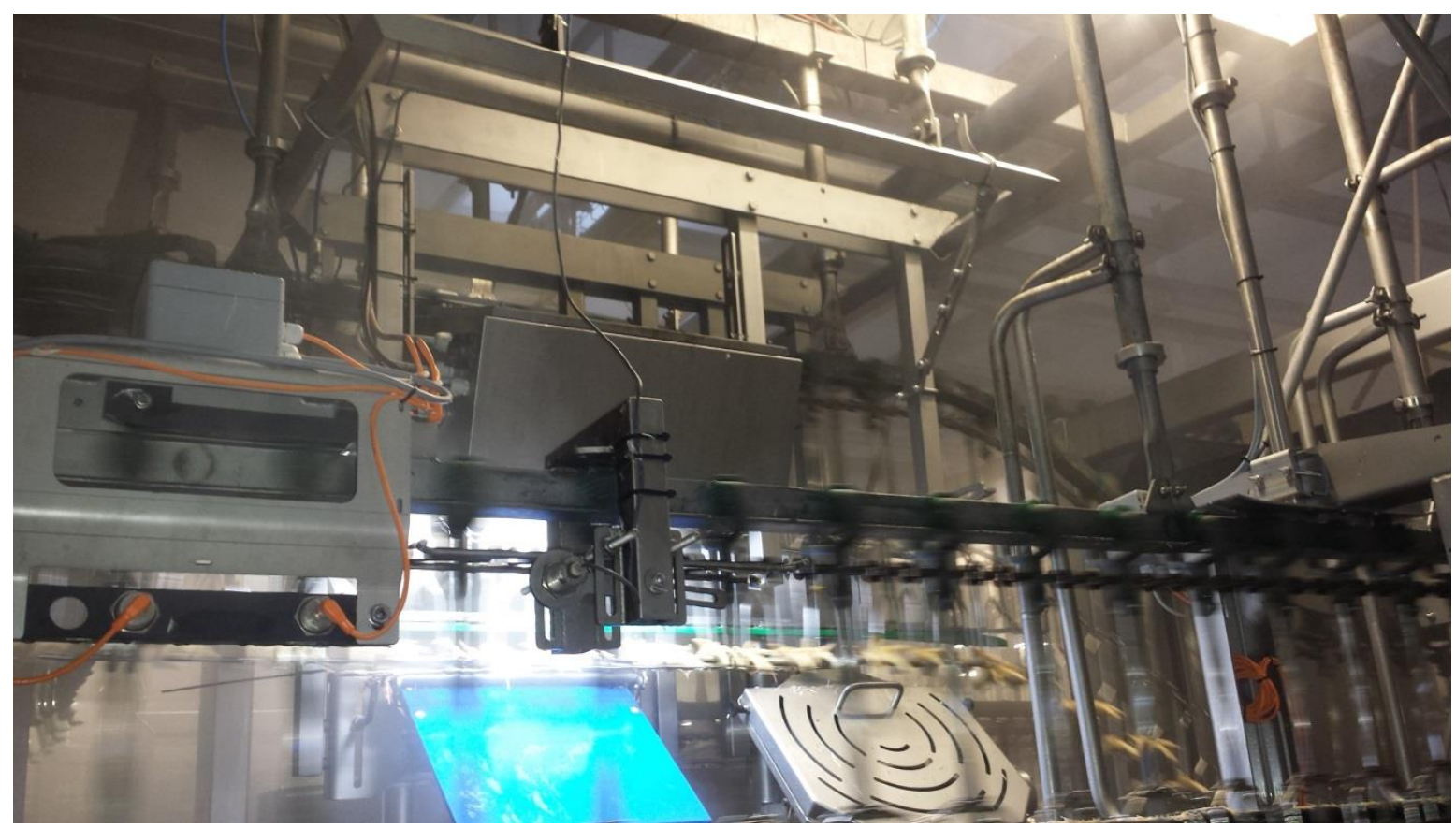

Figure 2.2 Camera set-up in the slaughterhouse.

Figure 2.3 shows how the feet are brought towards the camera's objective and an example of the system's display. 


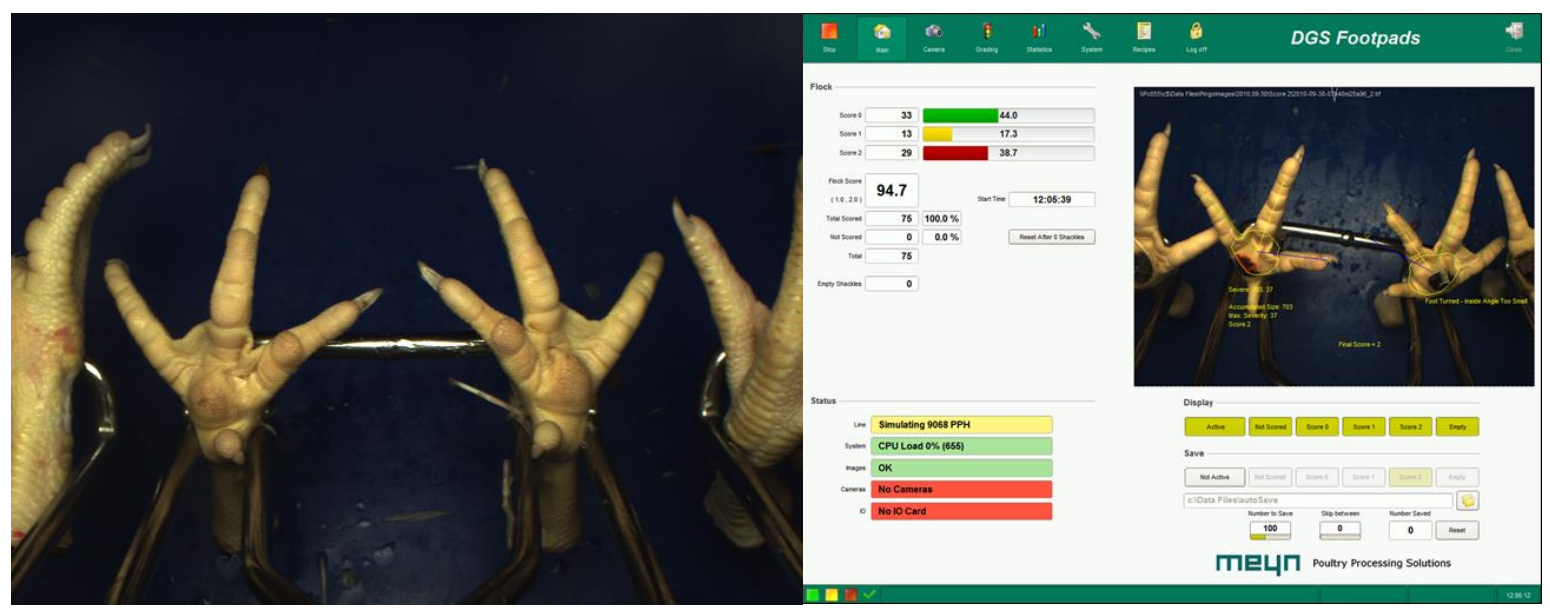

Figure 2.3 Left: camera image of the feet in the slaughterhouse shackles during measurement (these feet obtained a score of 0); right: system display.

\subsection{Collection of feet and images}

On Monday 20 February 2017 and Monday 15 May 2017, a visit was made to the slaughterhouse and samples were taken from all flocks of broiler chickens slaughtered on that day. A flock is defined as all animals from the same broiler house delivered at the same time to the slaughterhouse. One to four samples were taken per flock. In each sample, 400 pairs of feet were measured by the camera, whilst the trained Wageningen Livestock Research inspector manually assessed 100 right feet of these 400 pairs. It was not possible to make a one-to-one comparison because of the speed of the lines (approximately 12,000 chicks per hour). The procedure was as follows: at the beginning of the slaughtering day, two clocks were synchronised with the clock on the computer. Then, 100 right feet were collected from the slaughter line just after the camera. The start and end times were noted. In the time during which 100 right feet were manually collected from the slaughter line, the camera assessed the feet (both left and right) of approximately 400 chicks. The camera images from the collection period were saved. Then the footpad lesion score of these saved images was assessed with the (updated) software. The footpad lesion score from these images was compared with the manual score from the 100 right feet collected. On the first slaughtering day (20 February 2017) twenty samples were taken from seven flocks from four broiler houses. On the second slaughtering day (15 May 2017) fifteen samples were taken from eleven flocks from six different broiler houses.

The latest software settings (annex 1 and 2) were used to assess the camera images. The software includes a slaughterhouse-specific segment for positioning the feet in the middle of the camera view. The software also has a segment for recognising lesions which is the same for each slaughterhouse. Finally, there is a setting to recognise the class limit. This differs between hard and soft scald slaughter lines. During both measurement days, the settings were changed over the course of the day from 'soft scald' to 'hard scald'. This means that on both measurement days, both soft scald and hard scald flocks were assessed. In the analysis of the data, it was also ascertained whether this had any influence on the correlation between the camera score and the reference score. During the validations, the temperature in the scalding tank varied between $50.5^{\circ} \mathrm{C}$ and $59^{\circ} \mathrm{C}$ for hard scald and between $51.5^{\circ} \mathrm{C}$ and $52.2^{\circ} \mathrm{C}$ for soft scald. These temperature settings (and the duration in the scald tank zones) are slaughterhouse-specific.

\subsection{Comparison of camera and manual measurement}

To assess the video-imaging system, it is important to establish how the scoring of the video-imaging system correlates with the scoring of the trained Wageningen Livestock Research inspector, abbreviated here to 'WLR inspector'. The feet are assessed using a score card developed by Wageningen Livestock Research in 2011 and fine-tuned in 2014 (score card version 1.3 - Annex 3). The scoring method is based on the 'Swedish scoring method' for footpad lesions (Berg, 1998). 
This method distributes footpad lesions across three classes, which can be summarised as follows:

- Class 0: no lesions; no discolouration or very mild brown discolouration of the footpad or virtually healed lesion;

- Class 1: mild lesions; superficial lesions, brown or black discolouration;

- Class 2: severe lesions; deep lesions, along with subcutaneous infection and/or scabs or swollen footpad (bumblefoot).

Only the footpad was included in the assessment (De Jong et al., 2011). The camera equally only assesses the footpad and does not take into account discolouration of the toes.

Data from the camera and manual footpad lesion inspections were compared as follows:

- comparison of percentage of lesions in classes 0, 1 and 2;

- comparison of footpad lesion scores (Footpad Score, FPS). The FPS was calculated as follows: FPS $=([$ number of feet class $1 \times 0.5]+$ [number of feet class $2 \times 2]) \times 100 /$ Ntotal (De Jong et al., 2011);

- Comparison of measurements of both footpads (keeping the severest score) with assessment of only the left or right foot.

\section{$2.4 \quad$ Data processing}

\subsubsection{Calculation of correlations}

Firstly, the correlations between the final camera scores and those of the WLR inspector were determined in the spreadsheet program Excel. The correlation found between the camera and the WLR inspector was compared with the desired situation of $100 \%$ correlation between the camera and the WLR inspector. The results at a flock level are provided in Chapter 3 and in the annex, the results are also provided at a sample level (sometimes there are several samples taken from one flock). When interpreting data, account must be taken of the limited size of this validation test.

\subsubsection{Statistical analysis}

The results were also analysed statistically using Genstat (version 18.1). The following model was used for this:

$$
\begin{aligned}
& \underline{Y}_{i j k l}=\beta_{0, i=1}+\beta_{1} * X_{i j k l}+\Delta \beta_{0, i=2}+\underline{\varepsilon}_{i j}+\underline{\varepsilon}_{i j k}+\underline{\varepsilon}_{i j k l} \\
& \text { With: } \\
& \underline{Y}_{i j k l} \text { : } \\
& x: \\
& \beta_{0, i=1} \text { : } \\
& \beta_{1} \\
& \Delta \beta_{0, i=2} \\
& \underline{\varepsilon}_{i j} \\
& \underline{\varepsilon}_{i j k} \\
& \underline{\varepsilon}_{i j k l}
\end{aligned}
$$




\subsubsection{Comparison of measurement of both footpads with assessment of only the left or right foot}

The perception in the poultry sector is that the camera scores more "severely" than the manual inspectors. The reason given for this is that the video-imaging system scores both feet of an animal and saves the more severe score out of the two, whereas with manual scoring, only the right foot is scored. The video-imaging system's software is however designed to ensure that the footpad lesion score from both feet correlates with that of the reference score (gold standard), in which only the right foot is assessed. This study also looked at the differences in footpad lesion score between the WLR inspector and the video-imaging system when the camera measures both feet and saves the most severe score or only measures the left or right feet. 


\section{Results}

\subsection{Video-imaging system performance}

Table 3.1 shows for each sample test the total number of images collected, the number of assessed images, the number of unassessed images and the percentage of unassessed images. This table shows that on average across all samples, $1.0 \% \pm 1.1 \%$ of the images could not be assessed and therefore that 99 percent of all images (i.e.: broiler chickens) could be used.

Table 3.1 Total number of images collected, number of assessed images, number of unassessed images and percentage of images unassessed by the camera for each sample test per flock.

\begin{tabular}{|c|c|c|c|c|c|}
\hline \multirow[t]{2}{*}{ Sample test } & \multirow[t]{2}{*}{ Flock } & \multirow{2}{*}{$\begin{array}{c}\text { Total } \\
\mathrm{n}\end{array}$} & \multirow{2}{*}{$\begin{array}{c}\text { Assessed } \\
n\end{array}$} & \multicolumn{2}{|c|}{ Unassessed } \\
\hline & & & & $\mathrm{n}$ & $\%$ \\
\hline 1 & 1 & 393 & 392 & 1 & 0.3 \\
\hline 3 & 2 & 393 & 392 & 1 & 0.3 \\
\hline 4 & 2 & 358 & 356 & 2 & 0.6 \\
\hline 6 & 3 & 372 & 369 & 3 & 0.8 \\
\hline 7 & 3 & 367 & 365 & 2 & 0.5 \\
\hline 8 & 4 & 412 & 412 & 0 & - \\
\hline 9 & 4 & 374 & 373 & 1 & 0.3 \\
\hline 13 & 5 & 345 & 343 & 2 & 0.6 \\
\hline 14 & 5 & 441 & 440 & 1 & 0.2 \\
\hline 15 & 6 & 438 & 437 & 1 & 0.2 \\
\hline 16 & 6 & 442 & 439 & 3 & 0.7 \\
\hline 17 & 6 & 423 & 423 & 0 & - \\
\hline 18 & 6 & 344 & 343 & 1 & 0.3 \\
\hline 19 & 7 & 412 & 408 & 4 & 1.0 \\
\hline 20 & 7 & 376 & 375 & 1 & 0.3 \\
\hline 26 & 11 & 348 & 348 & 0 & - \\
\hline 27 & 12 & 398 & 389 & 9 & 2.3 \\
\hline 28 & 12 & 330 & 325 & 5 & 1.5 \\
\hline 29 & 13 & 337 & 335 & 2 & 0.6 \\
\hline 30 & 13 & 297 & 296 & 1 & 0.3 \\
\hline 31 & 14 & 497 & 485 & 12 & 2.4 \\
\hline 32 & 15 & 361 & 351 & 10 & 2.8 \\
\hline 33 & 16 & 404 & 396 & 8 & 2.0 \\
\hline 34 & 17 & 409 & 399 & 10 & 2.4 \\
\hline 35 & 18 & 346 & 330 & 16 & 4.6 \\
\hline
\end{tabular}




\subsection{Comparison per score class}

In figures 3.1 to 3.3 , the correlations between the video-imaging system and the trained WLR inspector are shown per score class at a flock level. This shows good correlation between the videoimaging system and the WLR inspector for footpad score classes $0\left(R^{2}=0.99\right)$ and $2\left(R^{2}=0.95\right)$. For score class 1 , the video-imaging system shows an overestimation $\left(R^{2}=0.40\right)$. For score class 1 the system has to deal with two limits (score 0 vs 1 and 1 vs 2). Annex 4 shows the scores per class of both the WLR inspector and of the video-imaging system per sample and annex 5 shows the correlations between the WLR inspector and the video-imaging system per score class as well as at a sample test level.

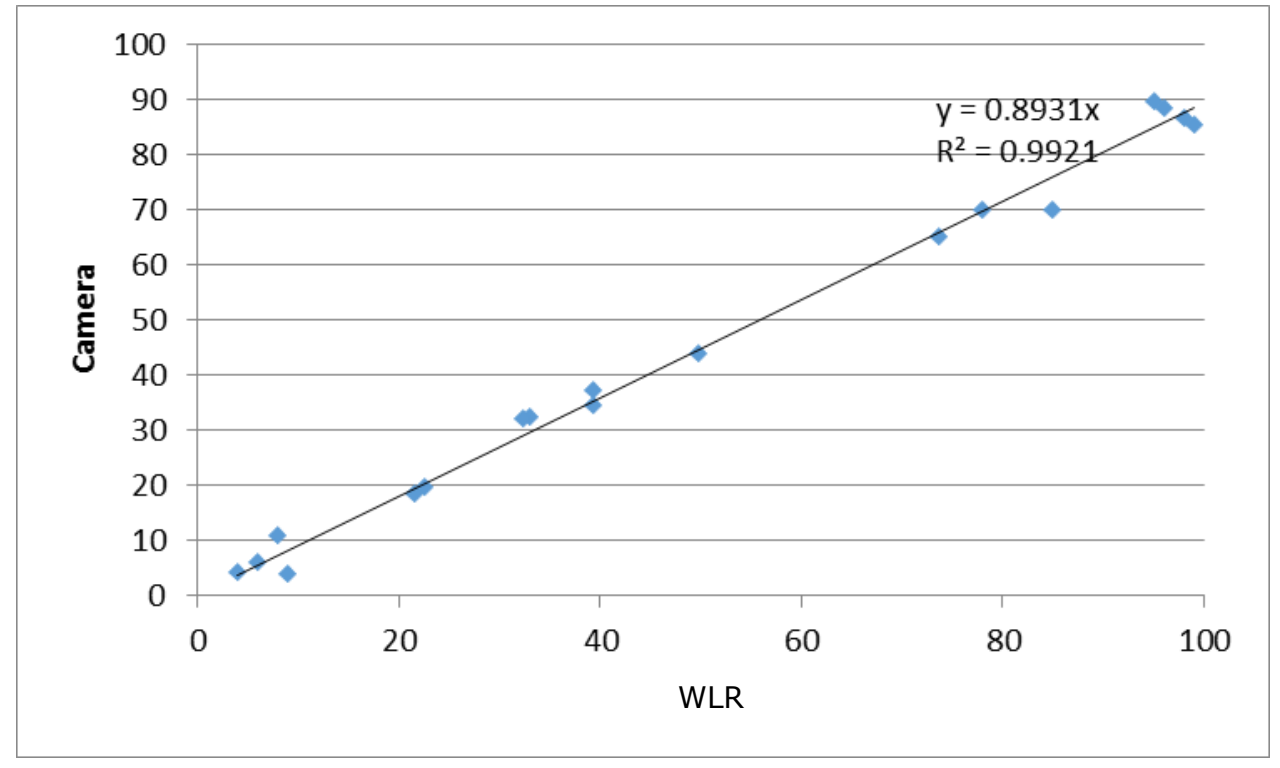

Figure 3.1 Correlation between camera and trained WLR inspector for class 0 (no lesion). The axes show the percentage of feet scored by WLR or the camera in class 0 (per flock). The black line shows the situation in the case of $100 \%$ correlation between the camera and the WLR inspector.

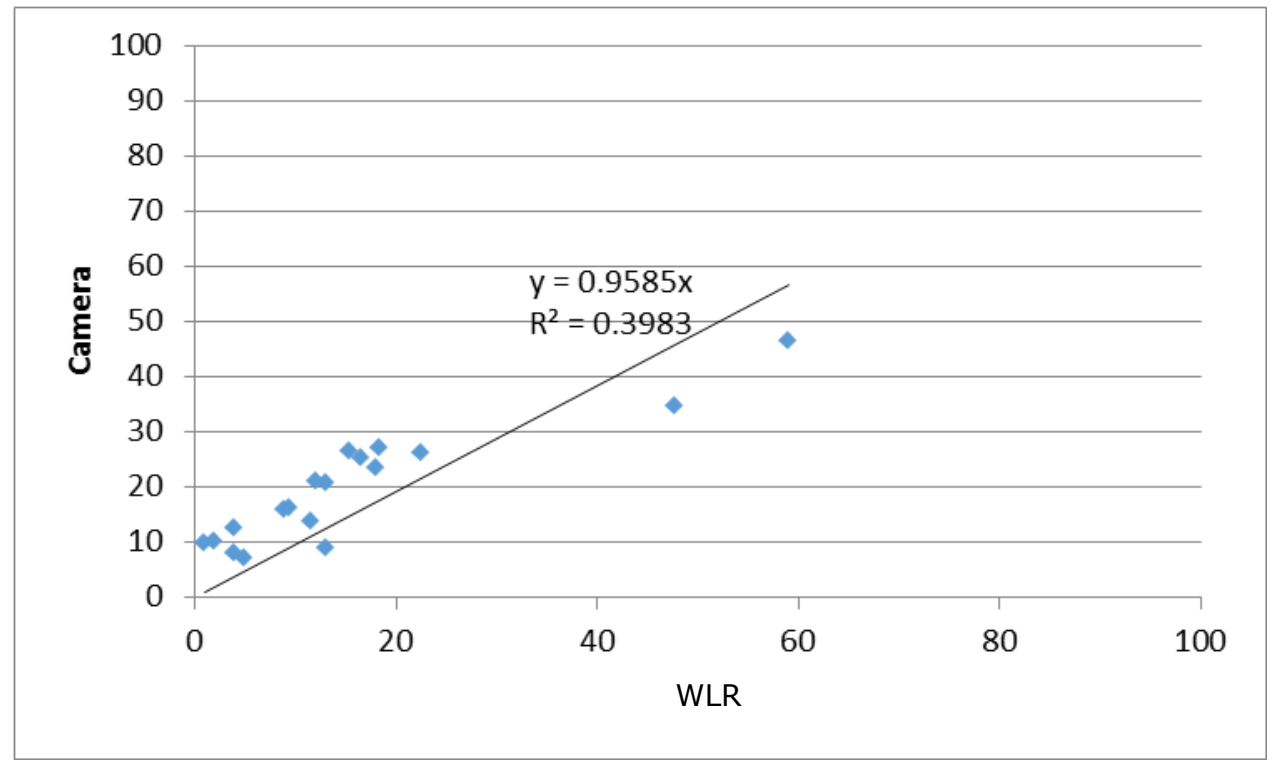

Figure 3.2 Correlation between camera and trained WLR inspector for class 1 (mild lesion). The axes show the percentage of feet scored by WLR or the camera in class 1 (per flock). The black line shows the situation in the case of $100 \%$ correlation between the camera and the WLR inspector. 


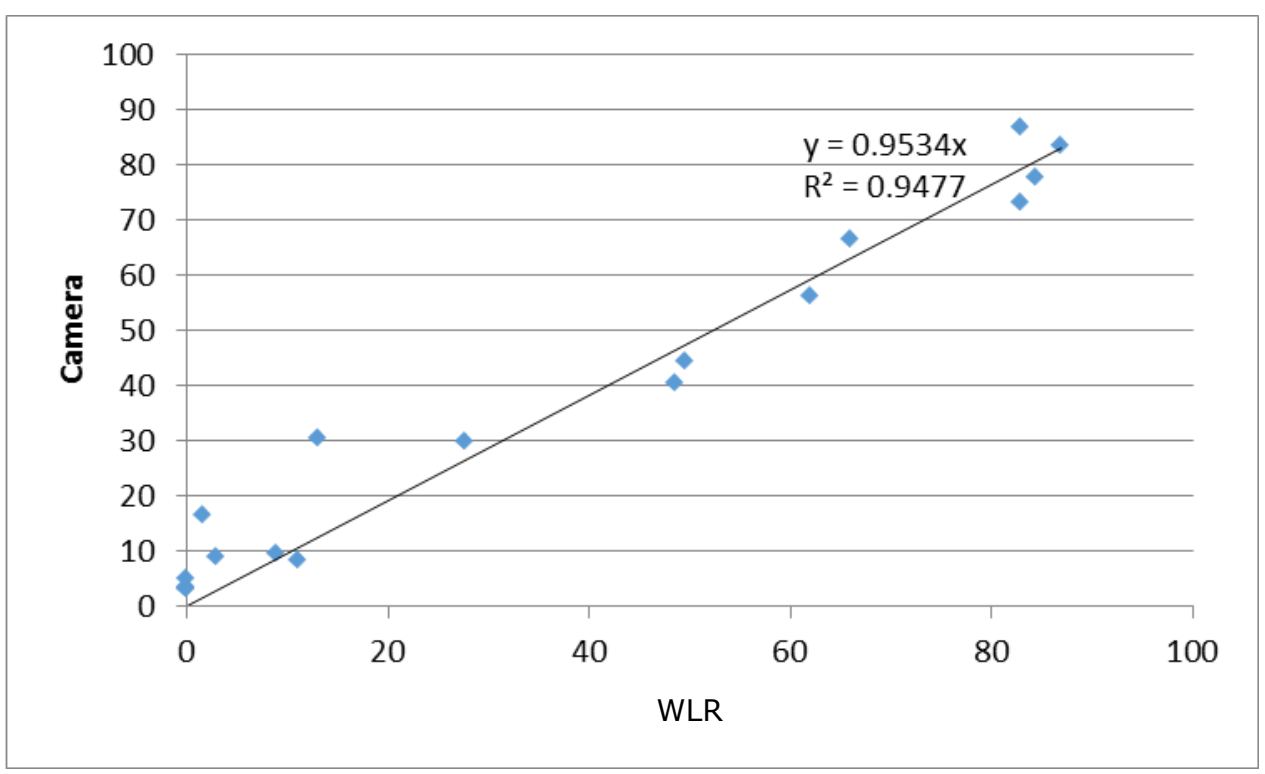

Figure 3.3 Correlation between camera and trained WLR inspector for class 2 (severe lesion). The axes show the percentage of feet scored by WLR or the camera in class 2 (per flock). The black line shows the situation in the case of $100 \%$ correlation between the camera and the WLR inspector.

\subsection{Comparison of footpad lesion score}

Figure 3.4 shows the footpad lesion scores of all flocks (18 in total) from the video-imaging system next to those of the WLR inspector. We can see that the footpad lesion scores from the video-imaging system correlate well with the scores from the trained WLR inspector. It can be noted however that in flocks with low footpad lesion scores (FPS $<60$ ), the video-imaging system scores structurally (slightly) higher than the WLR inspector. It can also be noted that the video-imaging system gave too high a score in flock numbers 3 and 4. Both flocks came from the same broiler house. In annex 7, the footpad lesion scores from the video-imaging system and the WLR inspector are shown for all samples taken (35 in total) as well as the relationship between these scores.

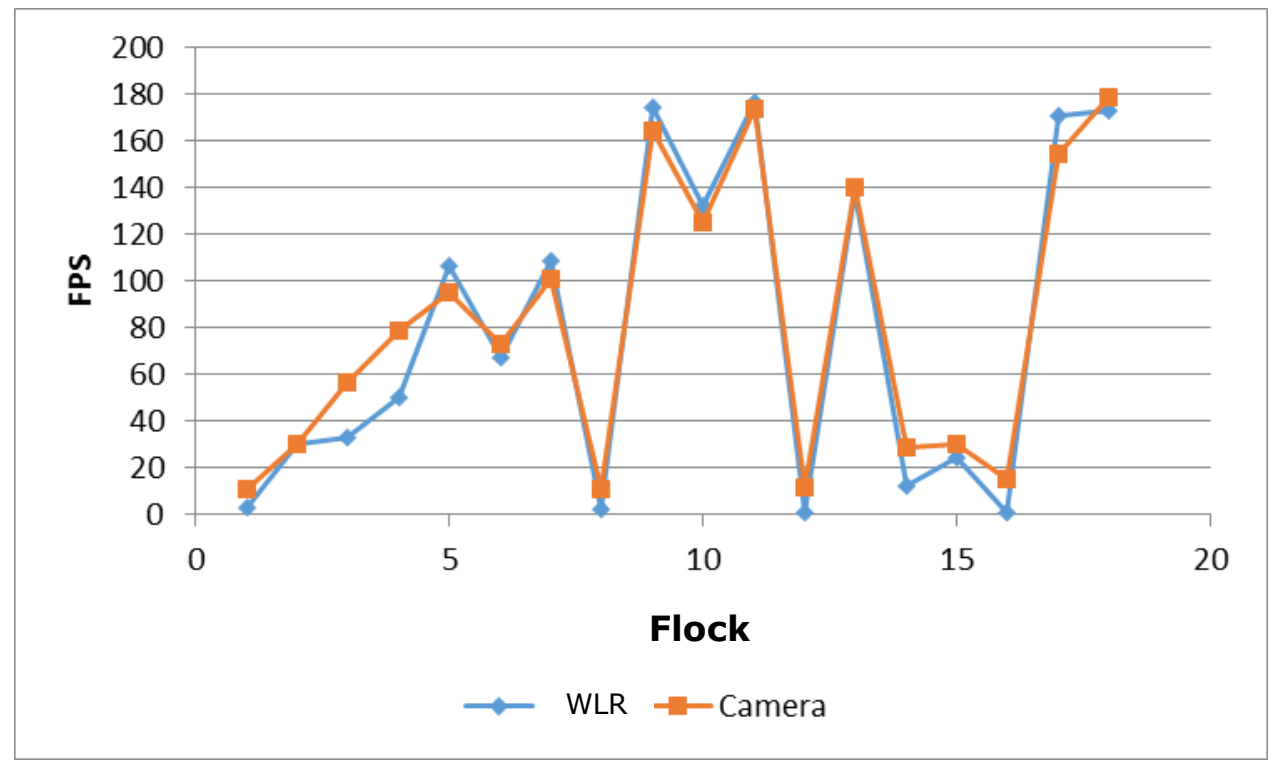

Figure 3.4 Graph of the differences in footpad lesion scores (FPS) per flock between the videoimaging system and the trained WLR inspector.

Figure 3.5 shows the relationship between the footpad lesion scores from the video-imaging system and the WLR inspector. This shows that the video-imaging system overestimates the footpad lesion score in flocks with a low incidence of severe footpad lesions (flocks with a low footpad lesion score), and in flocks with a high incidence of severe footpad lesions (flocks with a high footpad lesion score), 
it somewhat underestimates the footpad lesion score. This underestimation is in relative terms smaller than the overestimation of low footpad lesion scores.

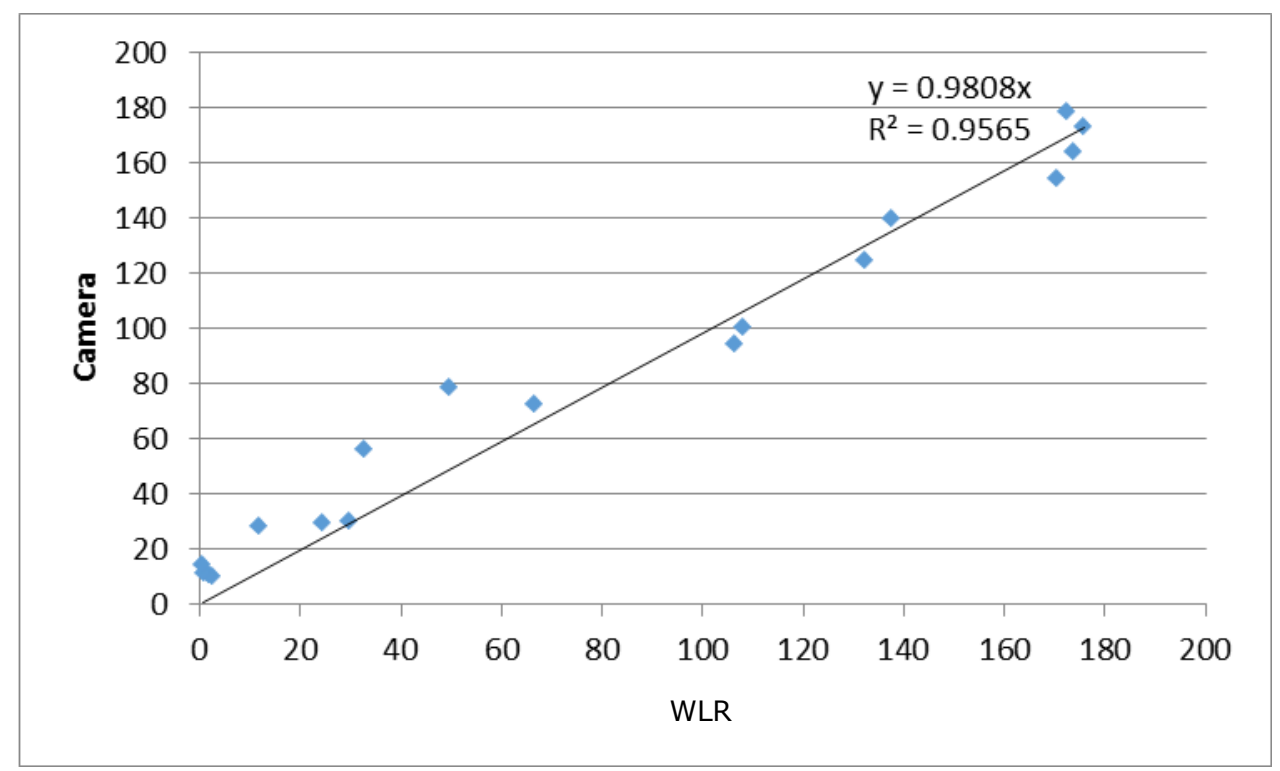

Figure 3.5 Relationship between the footpad lesion scores (FPS) per flock given by the camera and the trained WLR inspector. The black line shows the situation in the case of $100 \%$ correlation between the camera and the WLR inspector.

\subsection{Comparison between soft and hard scald}

Given that a previous validation showed that the type of scald affected the footpad lesion score, Meyn uses several recipes for soft and hard scald. This validation includes both soft-scald and hard-scald flocks. It appears that the type of scald did not affect the performance of the video-imaging system. In both soft and hard scald, the correlation between the footpad lesion scores from the video-imaging system and the trained WLR inspector was high ( $R^{2}$ in soft scald was 0.95 and in hard scald it was 0.97).

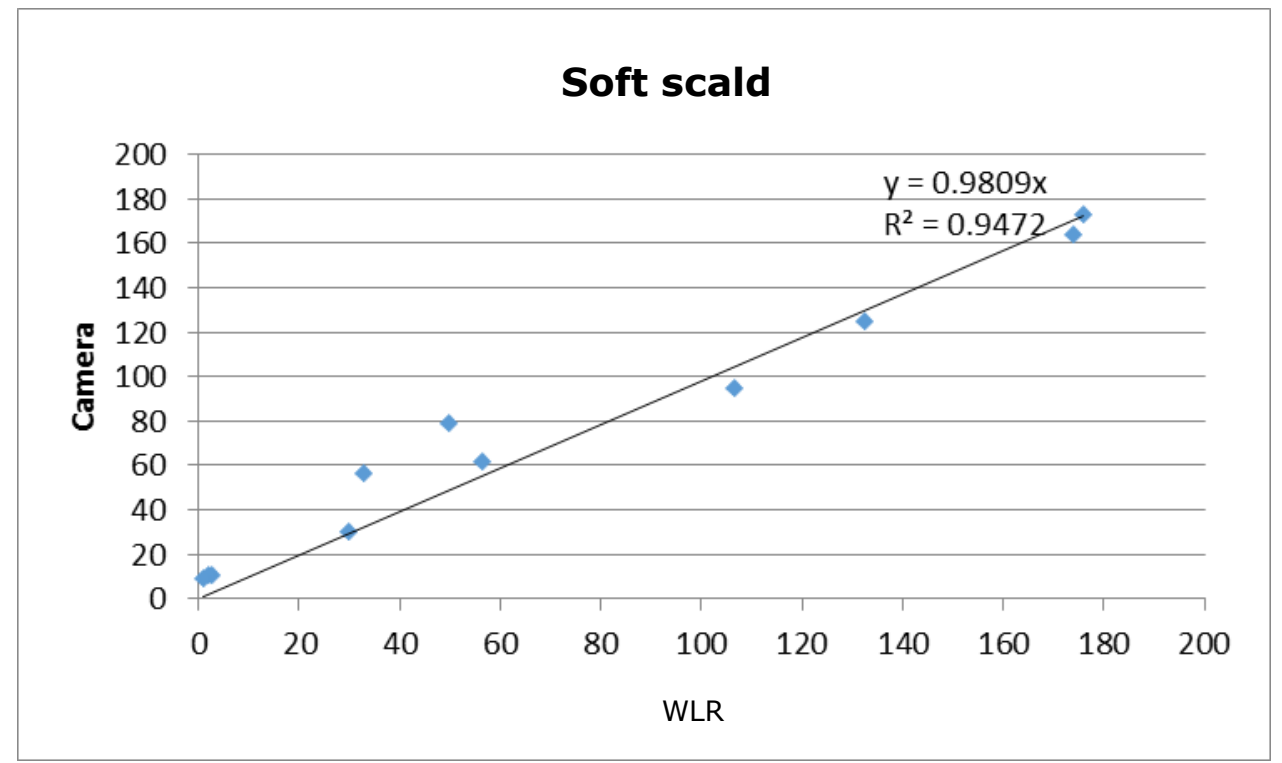

Figure 3.6 Relationship between the footpad lesion score (FPS) in all soft-scald flocks given by the camera and the trained WLR inspector. The black line shows the situation in the case of $100 \%$ correlation between the camera and the WLR inspector. 


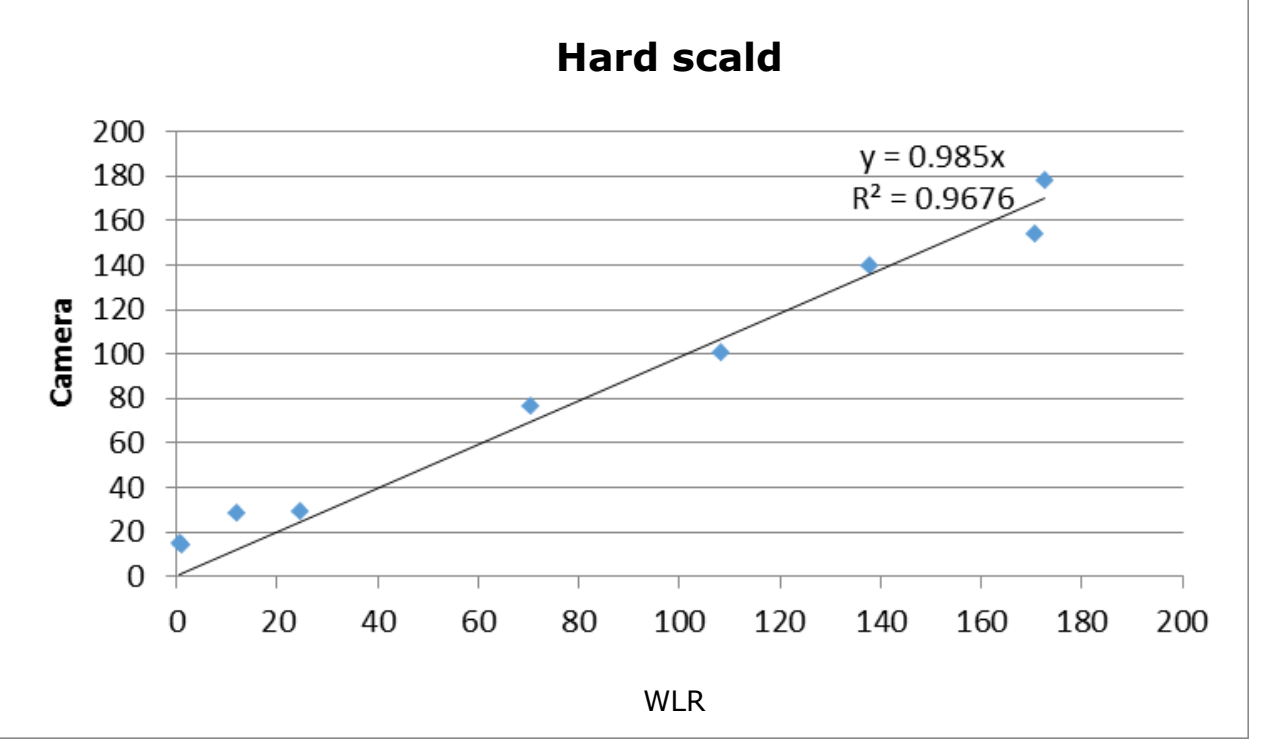

Figure 3.7 Relationship between the footpad lesion score (FPS) in all hard-scald flocks given by the camera and the trained WLR inspector. The black line shows the situation in the case of $100 \%$ correlation between the camera and the WLR inspector.

\subsection{Statistical analysis}

The results of the statistical analysis are provided in annex 11 . This analysis shows, like the aforementioned figures, that the camera overestimates for the low scores and underestimates slightly for the high scores compared with manual scoring. The statistical analysis shows that this effect is highest for hard scald.

This analysis also clearly shows that there is a "broiler house effect", which means that for a specific broiler house, the difference in the camera score can be greater. This means that the camera's errors are greater among the feet coming from certain broiler houses. The "broiler house effect" ascertained appeared to be extremely great for one particular broiler house, where the flock score from the camera was over 20 points higher than the score from the trained WLR inspector. The footpad lesion scores from this broiler house were all within a certain range (around the reference score of 50 points). Statistically, we can therefore not eliminate the possibility that the difference in lesions is type-specific (- large but superficial lesion) instead of broiler-house specific.

It should also be noted that this effect is also amplified because during the measurement, a relatively high amount of the samples were taken from the two flocks from this broiler house (in comparison with the other samples).

\subsection{Comparison of measurement of both footpads with assessment of only the left or right foot}

Figure 3.8 shows the comparison of the footpad lesion score from the WLR inspector and that of the video-imaging system based on 1 ) both feet (saving the most severe score), 2) only left feet and 3 ) only right feet. This showed that when the camera saves the most severe score of two feet, the final score is higher than when only the right or left foot is scored. The camera score for both feet, in which the most severe score is saved, correlates the most with the score from the trained WLR inspector. This is hardly surprising given that this is what the software is based on. The final scores from just the right or left feet are clearly lower than those of the WLR inspector. The footpad lesion scores based on only the left feet were higher than those based on only the right feet, which is in line with previous research by De Jong et al. (2011). On average across all flocks, the footpad lesion score from the camera based on both feet (highest score saved), was 82, and on only left or right feet, 70 and 64 respectively (WLR inspector footpad lesion score: 78). 


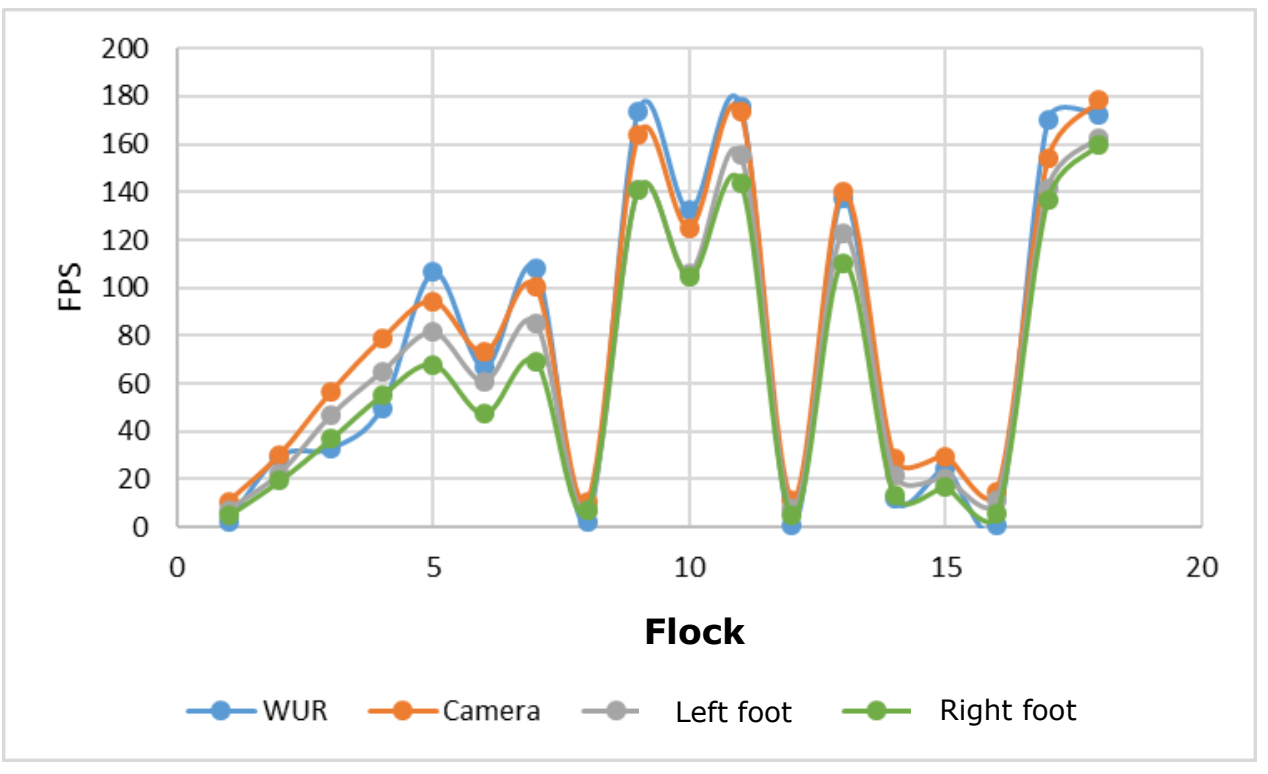

Figure 3.8 Comparison of WLR inspector and video-imaging system footpad lesion scores where the camera scores in three ways: both footpads (saving the most severe score), only the left foot or only the right foot. 


\section{Discussion}

The number of feet that could be assessed by the camera (99\%), is considerably above the $70 \%$ defined in previous research (De Jong et al., 2011). This means that with the Meyn Footpad Inspection System, the footpads of almost all broilers in a flock can be assessed. This is considered one of the greatest benefits of the system. It is known that variation can occur in the score within a flock, for example because wet litter (as a result of leaks, condensation, draughts, non-uniform light distribution etc.) in the broiler house can provoke an increase in footpad lesions in a part of the flock (De Jong et al., 2012). Because the camera can assess almost all broiler chickens, it will give a more reliable picture of the severity and incidence of footpad lesions in a flock compared to a manual measurement based on a sample test of only twice 50 feet collected around $30 \%$ and $60 \%$ of the processing of a flock (as determined in the regulation 'Regeling houders van dieren'). As an illustration, a sample of 100 feet on a small $(6,000)$ or large $(30,000)$ flock corresponds to $1.7 \%$ and $0.33 \%$ respectively. The camera measures both feet (with the final result based on the foot with the most severe score), rather than just the right foot (which is what happens with a manual measurement). There is also the chance that an inspector (unintentionally) fails to score consistently, but adjusts the method depending on the severity of the footpad lesions in the flock. A camera will always measure in the same way. The videoimaging system is indeed costly, but it saves work, and images can be saved to allow the score to be checked afterwards (De Jong et al., 2011).

On both measurement days, a total of 18 flocks were measured. On average, the footpad lesion score across all eighteen flocks of the video-imaging system was somewhat higher than that of the trained WLR inspector: 82 compared to 78. Ten flocks had a footpad lesion score lower than 80, two flocks a score of between 80 and 120, and six flocks a score higher than 120 . This means that relatively few flocks were found to be in the range between 80 and 120 points. This was however inherent to the set-up chosen, i.e. the choice of flocks within a certain area with footpad lesion scores depends on what is delivered on the measurement days. Moreover, it was decided that a very limited validation should be conducted. Ideally, the validation would be conducted over more days than in the present study.

Overall, the correlation in footpad lesion scores between the camera and the trained WLR inspector is good. The camera scores in the low range (FPS between 0-60 points) slightly higher/more severely than the WLR inspector, while in the high range (FPS>120) the video-imaging system scores slightly lower/less severely. The difference between the camera and the trained inspector is greater for hard scald than for soft scald. In the mid range of FPS scores, the camera score correlates well with that of the trained WLR inspector. One of the possible causes for the camera scoring higher in the low range is the position of the foot in the shackle. This can cause the foot to be shown turned and/or the foot of another animal could appear in the picture, which the camera could interpret as a shadow, or the camera could measure the wrong area (not the footpad), meaning that a class 0 lesion (no lesion) is seen by the camera as a class 1 or class 2 lesion. Annex 8 shows a few examples of inaccurate measurements by the video-imaging system. The research did not show that any remaining dirt in/on the lesion resulted in an incorrect assessment, but it cannot be ruled out that this could occur in practice. Another possible reasoning for the fact that the camera scores more severely in the low range (FPS 0-60 points) is that the chance of picking a right foot from the line with a lesion in a clean flock is relatively small, whilst the camera assesses all 400 feet. Every missed foot with a lesion is therefore not included in the manual measurement, whilst they are all included in the camera measurement.

The statistical analysis shows that there could be a "broiler house effect", potentially connected to the range in which the broiler house's score falls. It cannot therefore be excluded that the system shows a higher difference with certain types of feet. However, to be able to expand on this theory, a more thorough study is needed based on a larger number of flocks. 
The video-imaging system's validation was a very limited validation due to financial constraints. This means that there are a number of points and recommendations outstanding for a more thorough validation:

- In this version, extra samples were taken from the same flock if a greater difference could be seen between a flock's score and the score from the trained WLR inspector. From a technical point-ofview, this is not a correct way of sampling. If we want to ascertain whether differences within a flock can be correlated, the same number of samples should be taken from every flock. However, because of the limited amount of samples, we opted to include all samples in the analysis.

- Ideally, the assessor should not be aware of the video-imaging system's score after his/her assessment but because we wanted to ascertain the camera's performance, the score was provided and if the camera's score differed from that of the WLR inspector, a new sample was taken within the same flock. This was done to obtain a better insight into the difference between the videoimaging system and the WLR inspector.

- The samples were taken on two days. The camera software that converts the images into scores was adapted after the first sample day (with information per sample of the reference scores from the first day). Strictly speaking, the data from the first day were therefore not suitable to be used as validation data. Because of the reduced number of flocks and samples there would be if we only used the samples from the second day, they were included in this report, in which all images from both measurement days are assessed with the new version of the software.

- On both measurement days, over the course of the day the settings were switched from 'soft scald' to 'hard scald'. This means that the scald method goes hand-in-hand with the tiredness of the WLR inspector. A human can conceivably be "fitter" at the beginning of the day, i.e. with soft scald, than at the end of the day with hard scald. To eradicate this factor, the recommendation is to measure soft scald on a different day to hard scald, as it is not practical to switch to different scald methods between flocks.

Based on the very limited validation conducted here, it cannot be concluded that the footpad lesion score of the Meyn Footpad Inspection System differs considerably from that of the trained inspector. Given the large degree of correlation of the footpad lesion scores from the video-imaging system and the trained WLR inspector, and the fact that the video-imaging system is able to assess almost all chickens in a flock, the camera could even give a more reliable picture of the severity and incidence of footpad lesions in a flock than a manual measurement using a sample of only 100 feet, despite the fact that there may be a "broiler house effect" or a "type-of-lesion" effect which can cause a greater difference from the camera score.

The camera's software is programmed to obtain the best possible correlation between the score of the most severe foot of a pair of feet and the score of the WLR inspector. If only the score from the left or right foot is saved, the total score is lower, but it correlates less well with the score from the WLR inspector (which is logically a consequence of the fact that the camera is calibrated to the most severe score in a pair of feet). The fact that the camera saves the most severe score from a pair of feet can therefore not explain the potential difference seen in practice between the camera and the manual assessment.

In 2015, Wageningen Livestock Research also conducted a validation of the video-imaging system in another broiler chicken slaughterhouse (unpublished data). The images saved from this validation were assessed again with the new software. It appears that the footpad lesion scores from the videoimaging system correlate well with those of the WLR inspector (Figure 4.1 and $4.2 ; R^{2}=0.92$ ). This is therefore in line with the results of the validation described in this report. In 2015, a total of 8 flocks were measured. On average, the footpad lesion score across all eight flocks delivered to the videoimaging system was somewhat higher than that of the trained WLR inspector: 63 compared to 58. Six flocks had a footpad lesion score lower than 80 , two flocks a score of between 80 and 120, and there were no flocks with a score above 120 . 


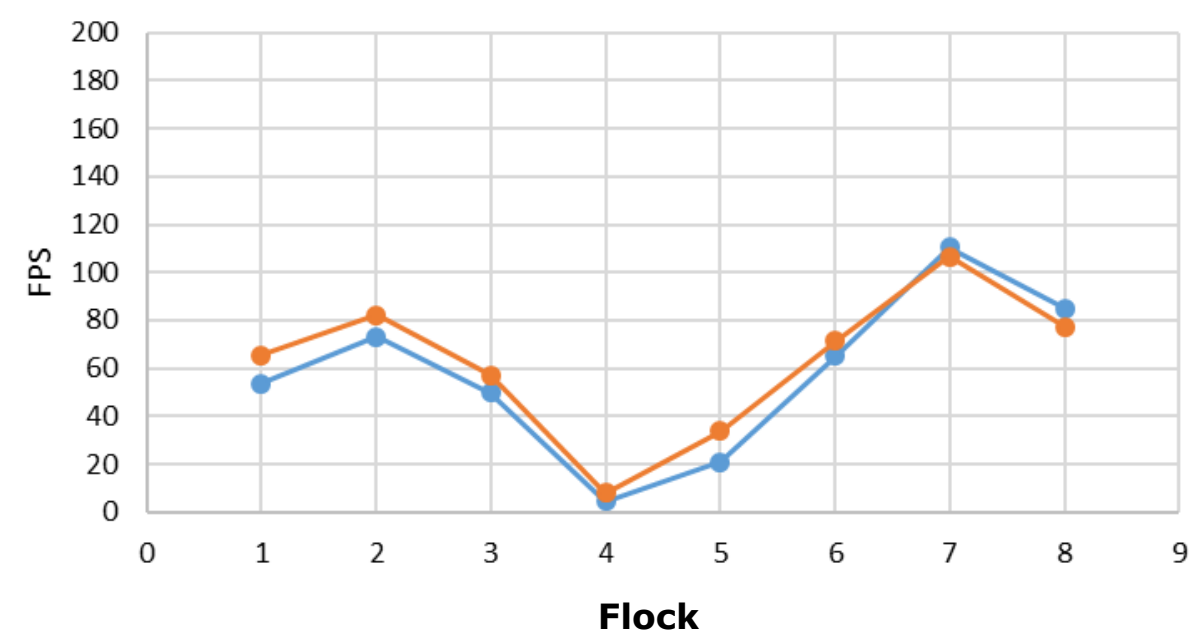

- WLR - Camera

Figure 4.1 Graph of the differences in footpad lesion scores (FPS) per flock between the videoimaging system and the trained WLR inspector based on the images of the validation of a broiler chicken slaughterhouse in 2015.

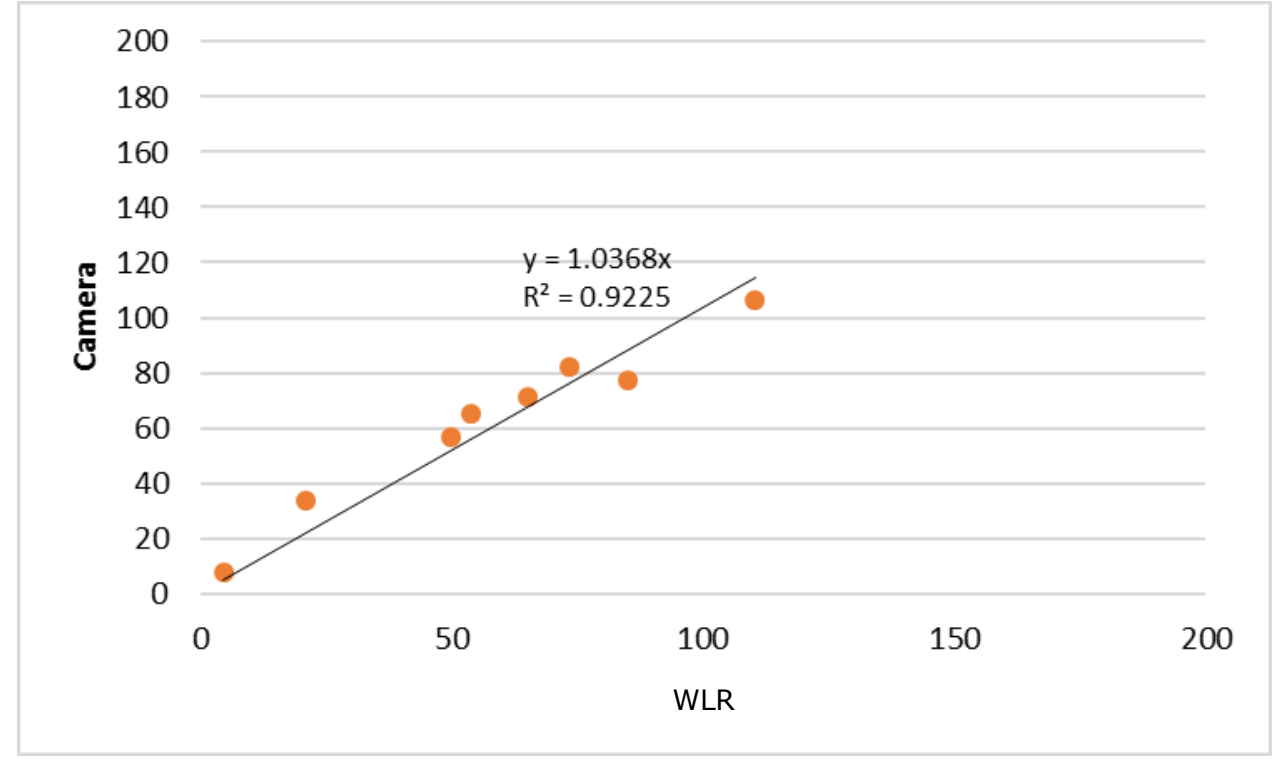

Figure 4.2 Relationship between the footpad lesion scores (FPS) per flock given by the camera and the trained WLR inspector based on the images of the validation conducted in 2015. The black line shows the situation in the case of $100 \%$ correlation between the camera and the WLR inspector. 


\section{Conclusions}

Based on this limited comparison of footpad lesion inspection by the Meyn Footpad Inspection System and manually by a trained WLR inspector, the video-imaging system's scores appear to correlate well with those of the trained WLR inspector. Given the large degree of correlation of the footpad lesion scores given by the video-imaging system and the trained WLR inspector, and the fact that the videoimaging system is able to assess almost all chickens in a flock, the camera could even give a more reliable picture of the severity and incidence of footpad lesions in a flock than a manual measurement using a sample of only 100 feet. It is however possible that there is a "broiler house effect" or a "typeof-lesion effect" which can cause the camera score to differ. A video-imaging system will also measure more uniformly across all slaughterhouses, while there could possibly be a variation in the quality of the manual measurements on different broiler chicken slaughterhouses, but also within slaughterhouses (between different people).

The camera assessed the lesions slightly more severely than the WLR inspector. As a result, the footpad lesion score from the video-imaging system was higher than that from the WLR inspector (FPS 82 vs. 78). The video-imaging system made a slight overestimation in flocks with few footpad lesions (FPS $<60$ ), and in flocks with severe footpad lesions (FPS $>120$ ) a slight underestimation of the footpad lesion score. In the 60-120 point range, the camera scores well. The difference with the camera was somewhat greater with hard scald than with soft scald.

The camera's software is programmed to obtain the best possible correlation between the score of the most severe foot of a pair of feet and the score of the WLR inspector. The fact that the camera saves the most severe score from a pair of feet, and not only the right or left foot as standard, can therefore not explain the potential difference seen in practice between the camera and the manual assessment. This limited comparison/validation also proves this. 


\section{Literature}

Berg, C. (1998). Foot-pad dermatitis in broilers and turkeys. Doctoral diss. Dept. of Animal Environment and Health, SLU. Acta Universitatis Agriculturae Sueciae, Sweden.

COUNCIL DIRECTIVE 2007/43/EC of 28 June 2007. http://eurlex.europa.eu/LexUriServ/LexUriServ.do?uri=OJ:L:2007:182:0019:0028:EN:PDF

Jong, I.C. de; Reimert, H.G.M., Vanderhasselt, R., Gerritzen, M.A., Gunnink, H., Harn, J. van; Hindle, V.A., Lourens, A. (2011). Development of methods to monitor foot pad lesions in broiler chickens. Wageningen UR Livestock Research Report 463

Jong, I.C. de, Harn, J. van, Gunnink, H., Lourens, A., Riel, J.W. van (2012). Measuring foot-pad lesions in commercial broiler houses. Some aspects of methodology. Animal Welfare 21 (3), p. $325-330$.

Jong, I.C. de, 2013. Evaluation Meyn Footpad Inspection System. Wageningen UR Livestock Research Report 713. 


\section{Annex 1 Software recipe for soft scald}

\begin{tabular}{|c|c|c|c|}
\hline \multicolumn{4}{|l|}{ Camera } \\
\hline \multicolumn{4}{|l|}{ Haakpositie } \\
\hline Haakmidden & $\mathbf{x}$ & Voetenafstand & 300 \\
\hline \multicolumn{4}{|l|}{ Voetzoolpositie } \\
\hline Voetbreedtebereik & 70 & Onderkant negeren & 400 \\
\hline Voetdrempel & 30 & Vertikale Afwijking & 110 \\
\hline Teenlengte & 85 & Teenhoek & 33 \\
\hline Verklein Voetgebied & 15 & & \\
\hline \multicolumn{4}{|l|}{ Laesies } \\
\hline Gevoeligheid Rood & 77 & Gevoeligheid Groen & 60 \\
\hline Drempel & 24 & & \\
\hline Negeer heel klein & 79 & Ernstig bij Breedte & 20 \\
\hline Negeer lichtrood & 10 & & \\
\hline \multicolumn{2}{|c|}{ Negeer schaduw bovenaan } & \multicolumn{2}{|l|}{12} \\
\hline & & & \\
\hline \multicolumn{4}{|l|}{ Klassificatie } \\
\hline Score-drempels & Ernst & & Grootte \\
\hline Van 0 naar 1 & 13 & & 280 \\
\hline Van 1 naar 2 & 20 & & 1100 \\
\hline \multicolumn{4}{|l|}{ Bloemigheid } \\
\hline Van 2 naar 1 & 11 & & 250 \\
\hline \multicolumn{4}{|l|}{ Aspectratio } \\
\hline Van 1 naar 2 & AAN & & \\
\hline \multicolumn{4}{|l|}{ Extra Beslissing } \\
\hline Als & 13 & $<$ Ernst $<$ & 24 \\
\hline en $->$ dan score $=1$ & 350 & $<$ Grootte $<$ & 1300 \\
\hline \multicolumn{4}{|c|}{ Weegfactoren voor eindscore } \\
\hline Voor Score 1 & 0.5 & Voor Score 1 & 2.0 \\
\hline
\end{tabular}




\section{Annex 2 Software recipe for hard scald}

\begin{tabular}{|c|c|c|c|}
\hline \multicolumn{4}{|l|}{ Camera } \\
\hline \multicolumn{4}{|l|}{ Haakpositie } \\
\hline Haakmidden & $\mathbf{x}$ & Voetenafstand & 300 \\
\hline \multicolumn{4}{|l|}{ Voetzoolpositie } \\
\hline Voetbreedtebereik & 70 & Onderkant negeren & 400 \\
\hline Voetdrempel & 30 & Vertikale Afwijking & 110 \\
\hline Teenlengte & 85 & Teenhoek & 33 \\
\hline Verklein Voetgebied & 15 & & \\
\hline \multicolumn{4}{|l|}{ Laesies } \\
\hline Gevoeligheid Rood & 77 & Gevoeligheid Groen & 60 \\
\hline Drempel & 24 & & \\
\hline Negeer heel klein & 79 & Ernstig bij Breedte & 20 \\
\hline Negeer lichtrood & 10 & & \\
\hline \multicolumn{2}{|c|}{ Negeer schaduw bovenaan } & \multicolumn{2}{|l|}{12} \\
\hline \multicolumn{4}{|l|}{ Klassificatie } \\
\hline Score-drempels & Ernst & & Grootte \\
\hline Van 0 naar 1 & 13 & & 280 \\
\hline Van 1 naar 2 & 17 & & 800 \\
\hline \multicolumn{4}{|l|}{ Bloemigheid } \\
\hline Van 2 naar 1 & 11 & & 250 \\
\hline \multicolumn{4}{|l|}{ Aspectratio } \\
\hline Van 1 naar 2 & AAN & & \\
\hline \multicolumn{4}{|l|}{ Extra Beslissing } \\
\hline Als & 13 & $<$ Ernst $<$ & 20 \\
\hline en $->$ dan score $=1$ & 350 & $<$ Grootte < & 1000 \\
\hline \multicolumn{4}{|c|}{ Weegfactoren voor eindscore } \\
\hline Voor Score 1 & 0.5 & Voor Score 1 & 2.0 \\
\hline
\end{tabular}




\section{Annex 3 Score card footpad lesions broiler chickens version 1.3}

Scorekaart voetzoollaesies vleeskuikens (versie 1.3)

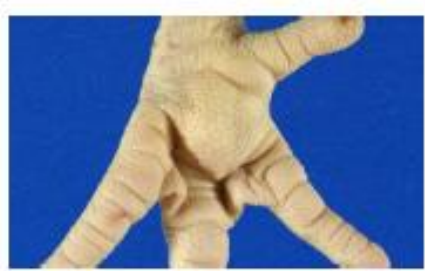

Klasse 0 - glad, geen laesie
Class 0 - smooth, no lesion

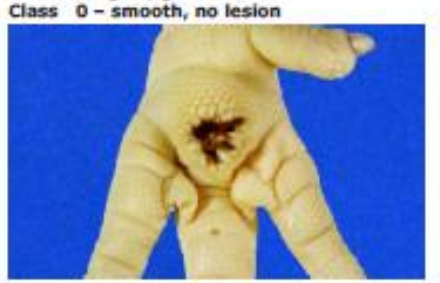

Klasse 1 - opperviakkige laesie, verkleuring Class 1 -superficial lesion, discolouration

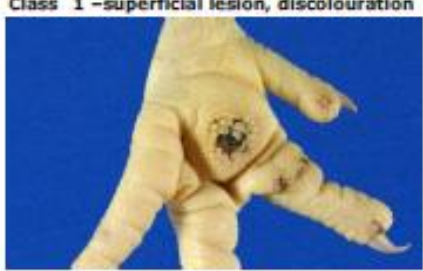

Klasse 2 - donkere papillen en zweer Class 2 - dark papiliae and uicer

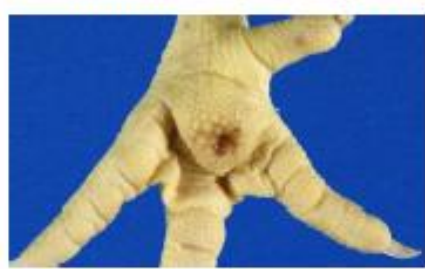

Klasse 0 - kleine verkleuring Class 0 - small discolouration

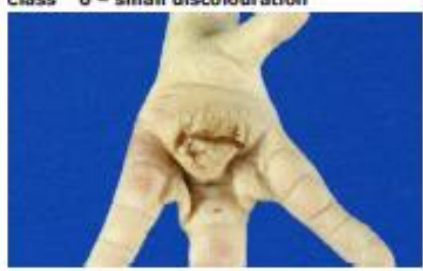

Klasse 1-donkere papillen, geen ontsteking

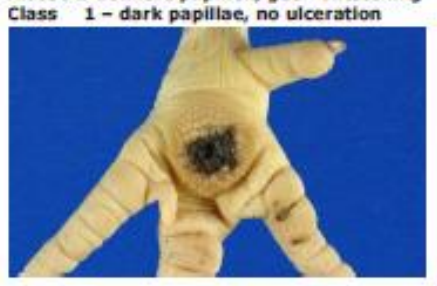

Klasse 2 - zweer bedekt met korst Class 2 - ulcer covered by crust

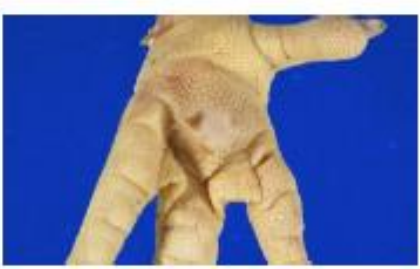

Klasse 0 - (bijna) genezen (litteken) Class 0 - (almost) healed lesion (scar)

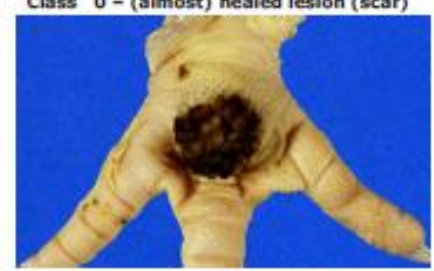

Klasse 1 - aanzientijke verkleuring Class 1 - substantial discolouration

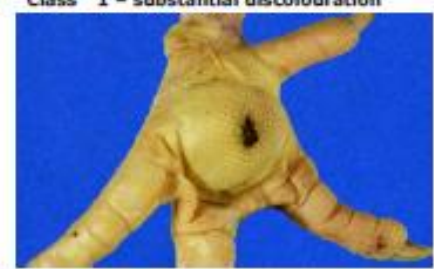

Klasse 2 - abces/'bumble foot', gezwollen Class 2 - abscess/bumble foot, swollen

Uitleg scorekaart voetzoollaesies vleeskuikens (Methodiek @Berg) - a photo guide to broiler foot health classification (version 1.3)

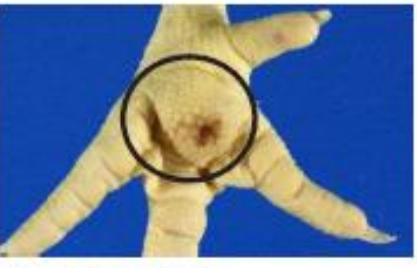

Klasse 0 - geen laesie Class 0- no lesion

Klasse 0 - Geen laesies: geen laesie of zeer kjeine en oppervakkige aantasting (geringe verkleuring $c 0$ een klein opperviak), milde Myperkeratose, (oude) littekens. Oppervlakte verkleuring heeft maximsal de grootte van een ludferkopje.

Alleen de voetzool (amcirkelde deel) wordt meegenomen in de becordeling

Class 0 - No lesion: no lesions or very smal and superficial lesions, slight discolouration on a limited area, mild hyperkeratosis, old scars. Maximum ares discolouration: size of a match head.

Onfy the foot path (dircled area) should be evaluated.

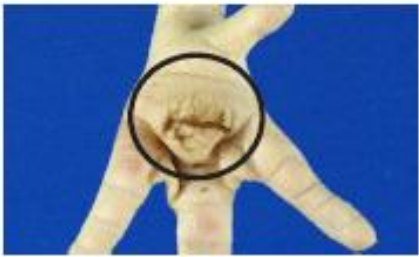

\section{Klasse 1 - milde laesie}

Klasse 1 - Milde laesie: verkleuring van de voetzod (groter dan een luciferkopje), oppervlakdige aantasting, vergrote en/of verkieurde papilien.

Alleen aantasting van de opperhuid.

Alleen de voetzool (omeirkelde ded) worde meegenomen in de beoardeling.

Class 1 - Mild lesion: discolouration of the foot pad (larger than the size of a match head), superficial damage, dark and/or large papillae.

Only the foot path (ainded ares) should be evaluated.

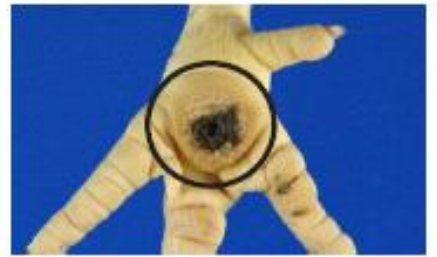

Klasse 2 - ernstige laesie Class 2 - severe lesion

Klasse 2 - Ernstige laesie: zweer met bloedkorsten van enige omvang, (tekenen van) blceduitstortingen of emstig gezwollen voetzolen (abces).

Aantasting tot in de diepere huidlagen.

Alleen de voetzoof (ancinkeide deef) wordt meegenomen in de beoordeling.

Class 2 - Severe lesion: Utcers with scabs of significant size, signs of haemorrthages or severely swollen foot pad (abscess).

Only the foot path (arded ares) should be evaluated.
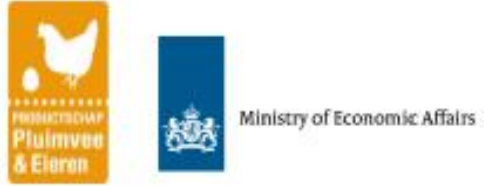


\section{Aanvulling scorekaart voetzoollaesies vleeskuikens (versie 1.3)}

Klasse 0: geen laesies

Voetzolen beoordeeld in klasse 0 (geen laesies) zijn voetzolen die niet of nauwelijks zijn aangetast. Als er sprake is van aantasting betreft het een zeer geringe lichtbruine verkleuring. De grootte van de aantasting bedraagt maximaal de grootte van het kopje van een lucifer. Voetzoollaesies kunnen genezen. Wanneer ze (bijna) volledig genezen zijn vallen ze ook onder klasse 0 , mits de resterende aantasting (verkleuring) kleiner is dan de grootte van een luciferkopje. Genezen voetzoollaesies zijn te herkennen aan de gladde huid (litteken).

\section{Klasse 1: milde laesies}

Klasse 1 laesies kunnen in diverse vormen voorkomen (zie scorekaart). De verkleuring verschilt ten opzichte van klasse 0 in de grootte: groter dan een luciferkopje. Ze verschillen van klasse 2 door de diepte van de aantasting: een klasse 1 laesie betreft altijd een oppervlakkige aantasting (alleen aantasting van de opperhuid). Vaak gaat verkleuring van de voetzool samen met hyperkeratose (vergrote papillen); hyperkeratose is altijd klasse 1. Soms is de huid rood en/of (licht) gezwollen

De aantasting/verkleuring van de voetzool kan zich uitstrekken tot een groot deel van de voetzool, maar als de aantasting oppervlakkig is valt deze altijd onder klasse 1 . De verkleuring kan variëren van lichtbruin tot donkerbruin/bijna zwart.

\section{Klasse 2: ernstige laesies}

Klasse 2 laesies gaan altijd gepaard met een zweer (open wond, afbraak opperhuid) of abces (zwelling met onderhuids pus). Verschil met klasse 1 laesies is dat de aantasting zich niet meer beperkt tot de opperhuid maar tot in de diepere huidlagen is of onderhuids. De aantasting kan klein zijn maar kan ook de hele voetzool beslaan (aantasting kan zich zelfs uitstekken tot de tenen maar deze worden niet meegenomen in de beoordeling). De verkleuring is meestal zeer donkerbruin tot zwart. De zweer is meestal bedekt met een korst.

In het geval van een abces spreken we bij vleeskuikens van een 'bumble foot'. Een abces kan maar hoeft niet samen te gaan met een (kleine) aantasting of verkleuring van de opperhuid. De zwelling is duidelijk herkenbaar en voelt als een 'verharde bal'. 'Bumble foot' komt niet vaak voor bij vleeskuikens. 


\section{Annex 4 Scores per class}

Table B4.1 Scores per class measured by the WLR inspector

\begin{tabular}{|c|c|c|c|c|c|c|c|c|c|c|}
\hline \multirow[t]{2}{*}{ Sample } & \multirow[t]{2}{*}{ Flock } & \multirow{2}{*}{$\begin{array}{c}\text { Scald } \\
\text { method }^{1}\end{array}$} & \multirow{2}{*}{$\begin{array}{c}\text { Measured } \\
\text { n }\end{array}$} & \multicolumn{2}{|c|}{ score 0} & \multicolumn{2}{|c|}{ score 1} & \multicolumn{2}{|c|}{ score 2} & \multirow{2}{*}{$\begin{array}{l}\text { FPS } \\
\text { score }\end{array}$} \\
\hline & & & & $\mathbf{n}$ & $\%$ & $\mathbf{n}$ & $\%$ & $\mathbf{n}$ & $\%$ & \\
\hline 1 & 1 & SS & 100 & 95 & 95 & 5 & 5 & 0 & 0 & 2.5 \\
\hline 2 & 2 & SS & 100 & 72 & 72 & 17 & 17 & 11 & 11 & 30.5 \\
\hline 3 & 2 & SS & 100 & 72 & 72 & 15 & 15 & 13 & 13 & 33.5 \\
\hline 4 & 2 & SS & 100 & 77 & 77 & 14 & 14 & 9 & 9 & 25.0 \\
\hline 5 & 3 & SS & 100 & 29 & 29 & 70 & 70 & 1 & 1 & 37.0 \\
\hline 6 & 3 & SS & 100 & 45 & 45 & 54 & 54 & 1 & 1 & 29.0 \\
\hline 7 & 3 & SS & 100 & 44 & 44 & 53 & 53 & 3 & 3 & 32.5 \\
\hline 8 & 4 & SS & 100 & 39 & 39 & 48 & 48 & 13 & 13 & 50.0 \\
\hline 9 & 4 & SS & 100 & 41 & 41 & 50 & 50 & 9 & 9 & 43.0 \\
\hline 10 & 4 & SS & 100 & 39 & 39 & 44 & 44 & 17 & 17 & 56.0 \\
\hline 11 & 4 & SS & 100 & 38 & 38 & 49 & 49 & 13 & 13 & 50.5 \\
\hline 12 & 5 & SS & 100 & 30 & 30 & 19 & 19 & 51 & 51 & 111.5 \\
\hline 13 & 5 & SS & 100 & 46 & 46 & 16 & 16 & 38 & 38 & 84.0 \\
\hline 14 & 5 & SS & 100 & 23 & 23 & 20 & 20 & 57 & 57 & 124.0 \\
\hline 15 & 6 & SS & 100 & 62 & 62 & 13 & 13 & 25 & 25 & 56.5 \\
\hline 16 & 6 & HS & 100 & 40 & 40 & 29 & 29 & 31 & 31 & 76.5 \\
\hline 17 & 6 & HS & 100 & 52 & 52 & 19 & 19 & 29 & 29 & 67.5 \\
\hline 18 & 6 & $\mathrm{HS}$ & 100 & 45 & 45 & 29 & 29 & 26 & 26 & 66.5 \\
\hline 19 & 7 & $\mathrm{HS}$ & 100 & 27 & 27 & 15 & 15 & 58 & 58 & 123.5 \\
\hline 20 & 7 & HS & 90 & 34 & 38 & 19 & 21 & 37 & 41 & 92.8 \\
\hline 21 & 8 & SS & 100 & 96 & 96 & 4 & 4 & 0 & 0 & 2.0 \\
\hline 22 & 9 & SS & 100 & 8 & 8 & 10 & 10 & 82 & 82 & 169.0 \\
\hline 23 & 9 & SS & 100 & 4 & 4 & 9 & 9 & 87 & 87 & 178.5 \\
\hline 24 & 10 & SS & 100 & 21 & 21 & 17 & 17 & 62 & 62 & 132.5 \\
\hline 25 & 10 & SS & 100 & 22 & 22 & 16 & 16 & 62 & 62 & 132.0 \\
\hline 26 & 11 & SS & 100 & 9 & 9 & 4 & 4 & 87 & 87 & 176.0 \\
\hline 27 & 12 & SS & 100 & 98 & 98 & 2 & 2 & 0 & 0 & 1.0 \\
\hline 28 & 12 & HS & 100 & 98 & 98 & 2 & 2 & 0 & 0 & 1.0 \\
\hline 29 & 13 & HS & 100 & 22 & 22 & 7 & 7 & 71 & 71 & 145.5 \\
\hline 30 & 13 & HS & 100 & 23 & 23 & 16 & 16 & 61 & 61 & 130.0 \\
\hline 31 & 14 & $\mathrm{HS}$ & 100 & 85 & 85 & 12 & 12 & 3 & 3 & 12.0 \\
\hline 32 & 15 & HS & 100 & 78 & 78 & 13 & 13 & 9 & 9 & 24.5 \\
\hline 33 & 16 & $\mathrm{HS}$ & 100 & 99 & 99 & 1 & 1 & 0 & 0 & 0.5 \\
\hline 34 & 17 & $\mathrm{HS}$ & 100 & 8 & 8 & 9 & 9 & 83 & 83 & 170.5 \\
\hline 35 & 18 & $\mathrm{HS}$ & 100 & 4 & 4 & 13 & 13 & 83 & 83 & 172.5 \\
\hline
\end{tabular}

1 SS = soft scald; HS = hard scald 
Table B4.2 Scores per class measured by video-imaging system

\begin{tabular}{|c|c|c|c|c|c|c|c|c|c|c|c|c|c|}
\hline \multirow[t]{2}{*}{ Measurement } & \multirow[t]{2}{*}{ Flock } & \multirow{2}{*}{$\begin{array}{c}\text { Scald } \\
\text { method }^{1}\end{array}$} & \multirow{2}{*}{$\begin{array}{c}\text { Total } \\
\text { n }\end{array}$} & \multirow{2}{*}{$\begin{array}{c}\text { Measured } \\
\text { n }\end{array}$} & \multicolumn{2}{|c|}{ Unmeasured } & \multicolumn{2}{|c|}{ score 0} & \multicolumn{2}{|c|}{ score 1} & \multicolumn{2}{|c|}{ score 2} & \multirow[t]{2}{*}{ FPS } \\
\hline & & & & & $\mathbf{n}$ & $\%$ & $\mathbf{n}$ & $\%$ & $\mathbf{n}$ & $\%$ & $\mathbf{n}$ & $\%$ & \\
\hline 1 & 1 & SS & 393 & 392 & 1 & 0.3 & 351 & 89.5 & 27 & 6.9 & 14 & 3.6 & 10.6 \\
\hline 2 & 2 & SS & 373 & 371 & 2 & 0.5 & 235 & 63.3 & 98 & 26.4 & 38 & 10.2 & 33.7 \\
\hline 3 & 2 & SS & 393 & 392 & 1 & 0.3 & 255 & 65.1 & 106 & 27.0 & 31 & 7.9 & 29.3 \\
\hline 4 & 2 & SS & 358 & 356 & 2 & 0.6 & 238 & 66.9 & 92 & 25.8 & 26 & 7.3 & 27.5 \\
\hline 5 & 3 & SS & 392 & 387 & 5 & 1.3 & 136 & 35.1 & 189 & 48.8 & 62 & 16.0 & 56.5 \\
\hline 6 & 3 & SS & 372 & 369 & 3 & 0.8 & 142 & 38.5 & 160 & 43.4 & 67 & 18.2 & 58.0 \\
\hline 7 & 3 & SS & 367 & 365 & 2 & 0.5 & 138 & 37.8 & 170 & 46.6 & 57 & 15.6 & 54.5 \\
\hline 8 & 4 & SS & 412 & 412 & 0 & 0.0 & 145 & 35.2 & 135 & 32.8 & 132 & 32.0 & 80.5 \\
\hline 9 & 4 & SS & 374 & 373 & 1 & 0.3 & 129 & 34.6 & 169 & 45.3 & 75 & 20.1 & 62.9 \\
\hline 10 & 4 & SS & 414 & 413 & 1 & 0.2 & 136 & 32.9 & 150 & 36.3 & 127 & 30.8 & 79.7 \\
\hline 11 & 4 & SS & 371 & 368 & 3 & 0.8 & 132 & 35.9 & 89 & 24.2 & 147 & 39.9 & 92.0 \\
\hline 12 & 5 & SS & 372 & 371 & 1 & 0.3 & 126 & 34.0 & 106 & 28.6 & 139 & 37.5 & 89.2 \\
\hline 13 & 5 & SS & 345 & 343 & 2 & 0.6 & 140 & 40.8 & 84 & 24.5 & 119 & 34.7 & 81.6 \\
\hline 14 & 5 & SS & 441 & 440 & 1 & 0.2 & 99 & 22.5 & 124 & 28.2 & 217 & 49.3 & 112.7 \\
\hline 15 & 6 & SS & 438 & 437 & 1 & 0.2 & 212 & 48.5 & 121 & 27.7 & 104 & 23.8 & 61.4 \\
\hline 16 & 6 & HS & 442 & 439 & 3 & 0.7 & 176 & 40.1 & 114 & 26.0 & 149 & 33.9 & 80.9 \\
\hline 17 & 6 & HS & 423 & 423 & 0 & 0.0 & 160 & 37.8 & 116 & 27.4 & 147 & 34.8 & 83.2 \\
\hline 18 & 6 & HS & 344 & 343 & 1 & 0.3 & 170 & 49.6 & 79 & 23.0 & 94 & 27.4 & 66.3 \\
\hline 19 & 7 & HS & 412 & 408 & 4 & 1.0 & 117 & 28.7 & 97 & 23.8 & 194 & 47.5 & 107.0 \\
\hline 20 & 7 & HS & 376 & 375 & 1 & 0.3 & 133 & 35.5 & 87 & 23.2 & 155 & 41.3 & 94.3 \\
\hline 21 & 8 & SS & 389 & 375 & 14 & 3.6 & 332 & 88.5 & 30 & 8.0 & 13 & 3.5 & 10.9 \\
\hline 22 & 9 & SS & 331 & 328 & 3 & 0.9 & 23 & 7.0 & 60 & 18.3 & 245 & 74.7 & 158.5 \\
\hline 23 & 9 & SS & 447 & 440 & 7 & 1.6 & 23 & 5.2 & 60 & 13.6 & 357 & 81.1 & 169.1 \\
\hline 24 & 10 & SS & 400 & 394 & 6 & 1.5 & 85 & 21.6 & 86 & 21.8 & 223 & 56.6 & 124.1 \\
\hline 25 & 10 & SS & 380 & 376 & 4 & 1.1 & 59 & 15.7 & 107 & 28.5 & 210 & 55.9 & 125.9 \\
\hline 26 & 11 & SS & 348 & 348 & 0 & 0.0 & 14 & 4.0 & 43 & 12.4 & 291 & 83.6 & 173.4 \\
\hline 27 & 12 & SS & 398 & 389 & 9 & 2.3 & 349 & 89.7 & 30 & 7.7 & 10 & 2.6 & 9.0 \\
\hline 28 & 12 & HS & 330 & 325 & 5 & 1.5 & 272 & 83.7 & 40 & 12.3 & 13 & 4.0 & 14.2 \\
\hline 29 & 13 & HS & 337 & 335 & 2 & 0.6 & 43 & 12.8 & 47 & 14.0 & 245 & 73.1 & 153.3 \\
\hline 30 & 13 & HS & 297 & 296 & 1 & 0.3 & 78 & 26.4 & 40 & 13.5 & 178 & 60.1 & 127.0 \\
\hline 31 & 14 & HS & 497 & 485 & 12 & 2.4 & 339 & 69.9 & 102 & 21.0 & 44 & 9.1 & 28.7 \\
\hline 32 & 15 & HS & 361 & 351 & 10 & 2.8 & 245 & 69.8 & 72 & 20.5 & 34 & 9.7 & 29.6 \\
\hline 33 & 16 & HS & 404 & 396 & 8 & 2.0 & 338 & 85.4 & 38 & 9.6 & 20 & 5.1 & 14.9 \\
\hline 34 & 17 & HS & 409 & 399 & 10 & 2.4 & 44 & 11.0 & 63 & 15.8 & 292 & 73.2 & 154.3 \\
\hline 35 & 18 & HS & 346 & 330 & 16 & 4.6 & 14 & 4.2 & 29 & 8.8 & 287 & 87.0 & 178.3 \\
\hline
\end{tabular}

1 SS = soft scald; HS = hard scald 


\section{Annex 5 Correlation per scoring class (based on samples)}

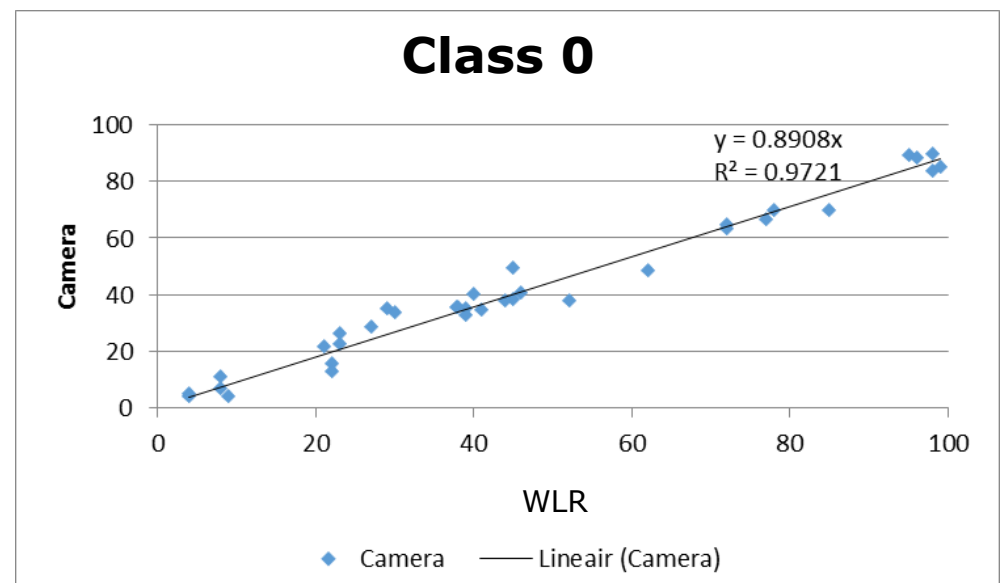

Figure B6.1 Correlation between camera and trained WLR inspector in class 0 (no lesion) based on all samples taken. The black line shows the situation in the case of $100 \%$ correlation between the camera and the WLR inspector.

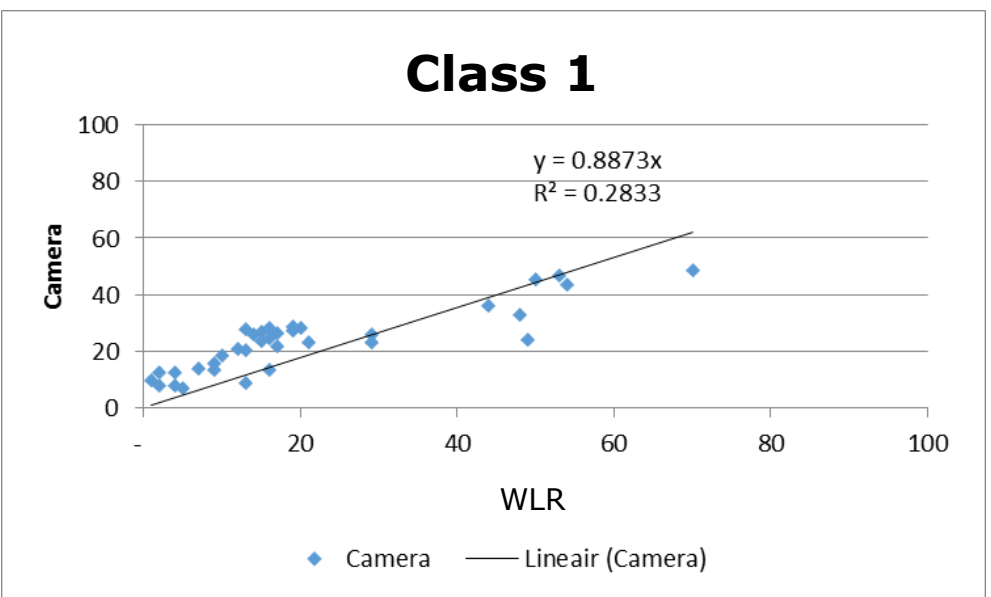

Figure B6.2 Correlation between camera and trained WLR inspector in class 1 (mild lesion) based on all samples taken. The black line shows the situation in the case of $100 \%$ correlation between the camera and the WLR inspector.

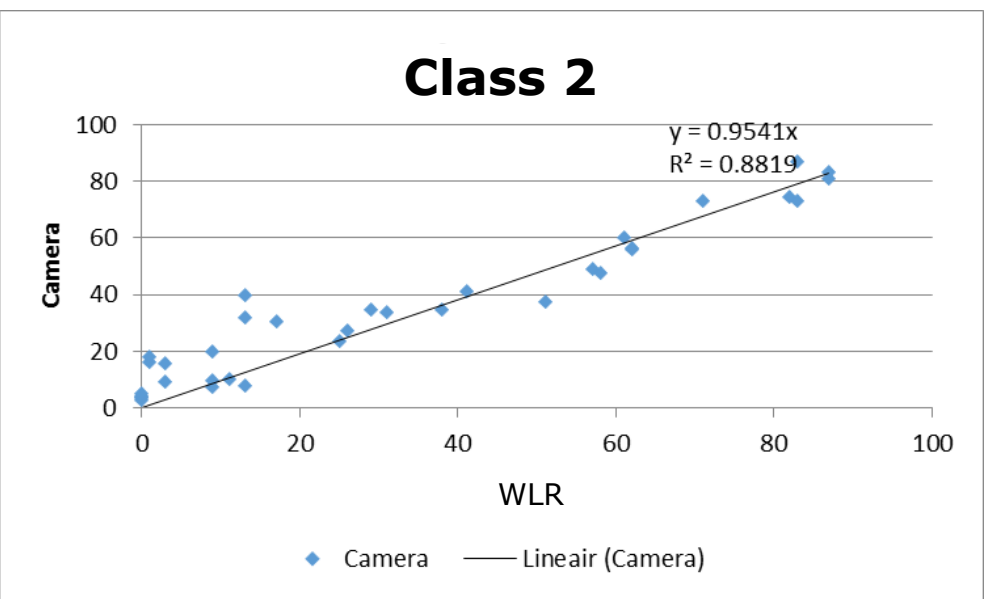

Figure B6.3 Correlation between camera and trained WLR inspector in class 2 (severe lesion) based on all samples taken. The black line shows the situation in the case of $100 \%$ correlation between the camera and the WLR inspector. 


\section{Annex 6 Footpad lesion scores per sample and at flock level}

Table B3.1 Footpad lesion score WLR and video-imaging system per measurement/sample

\begin{tabular}{|c|c|c|c|c|c|}
\hline Measurement & Flock & Scald & WLR & Camera & Difference \\
\hline 1 & 1 & Soft scald & 3 & 11 & 8 \\
\hline 2 & 2 & Soft scald & 31 & 34 & 3 \\
\hline 4 & 2 & Soft scald & 25 & 28 & 3 \\
\hline 5 & 3 & Soft scald & 37 & 56 & 19 \\
\hline 7 & 3 & Soft scald & 33 & 55 & 22 \\
\hline 8 & 4 & Soft scald & 50 & 80 & 30 \\
\hline 9 & 4 & Soft scald & 43 & 63 & 20 \\
\hline 10 & 4 & Soft scald & 56 & 80 & 24 \\
\hline 14 & 5 & Soft scald & 124 & 113 & -11 \\
\hline 15 & 6 & Soft scald & 57 & 61 & 5 \\
\hline 16 & 6 & Hard scald & 77 & 81 & 4 \\
\hline 17 & 6 & Hard scald & 68 & 83 & 16 \\
\hline 18 & 6 & Hard scald & 67 & 66 & 0 \\
\hline 19 & 7 & Hard scald & 124 & 107 & -17 \\
\hline 20 & 7 & Hard scald & 93 & 94 & 1 \\
\hline 21 & 8 & Soft scald & 2 & 11 & 9 \\
\hline 27 & 12 & Soft scald & 1 & 9 & 8 \\
\hline 28 & 12 & Hard scald & 1 & 14 & 13 \\
\hline 29 & 13 & Hard scald & 146 & 153 & 8 \\
\hline 30 & 13 & Hard scald & 130 & 127 & -3 \\
\hline 31 & 14 & Hard scald & 12 & 29 & 17 \\
\hline 32 & 15 & Hard scald & 25 & 30 & 5 \\
\hline 33 & 16 & Hard scald & 1 & 15 & 14 \\
\hline 34 & 17 & Hard scald & 171 & 154 & -16 \\
\hline 35 & 18 & Hard scald & 173 & 178 & 6 \\
\hline
\end{tabular}


Table B3.2 Footpad lesion score WLR and video-imaging system per flock

\begin{tabular}{|c|c|c|c|}
\hline Flock & WLR & Camera & Difference camera-WLR \\
\hline 1 & 3 & 11 & 8 \\
\hline 2 & 30 & 30 & 1 \\
\hline 3 & 33 & 56 & 23 \\
\hline 4 & 50 & 79 & 29 \\
\hline 5 & 107 & 95 & -12 \\
\hline 6 & 67 & 73 & 6 \\
\hline 7 & 108 & 101 & -8 \\
\hline 8 & 2 & 11 & 9 \\
\hline 9 & 174 & 164 & -10 \\
\hline 10 & 132 & 125 & -7 \\
\hline 11 & 176 & 173 & -3 \\
\hline 12 & 1 & 12 & 11 \\
\hline 13 & 138 & 140 & 2 \\
\hline 14 & 12 & 29 & 17 \\
\hline 15 & 25 & 30 & 5 \\
\hline 16 & 1 & 15 & 14 \\
\hline 17 & 171 & 154 & -16 \\
\hline 18 & 173 & 178 & 6 \\
\hline
\end{tabular}




\section{Annex 7 Footpad lesion scores per sample}

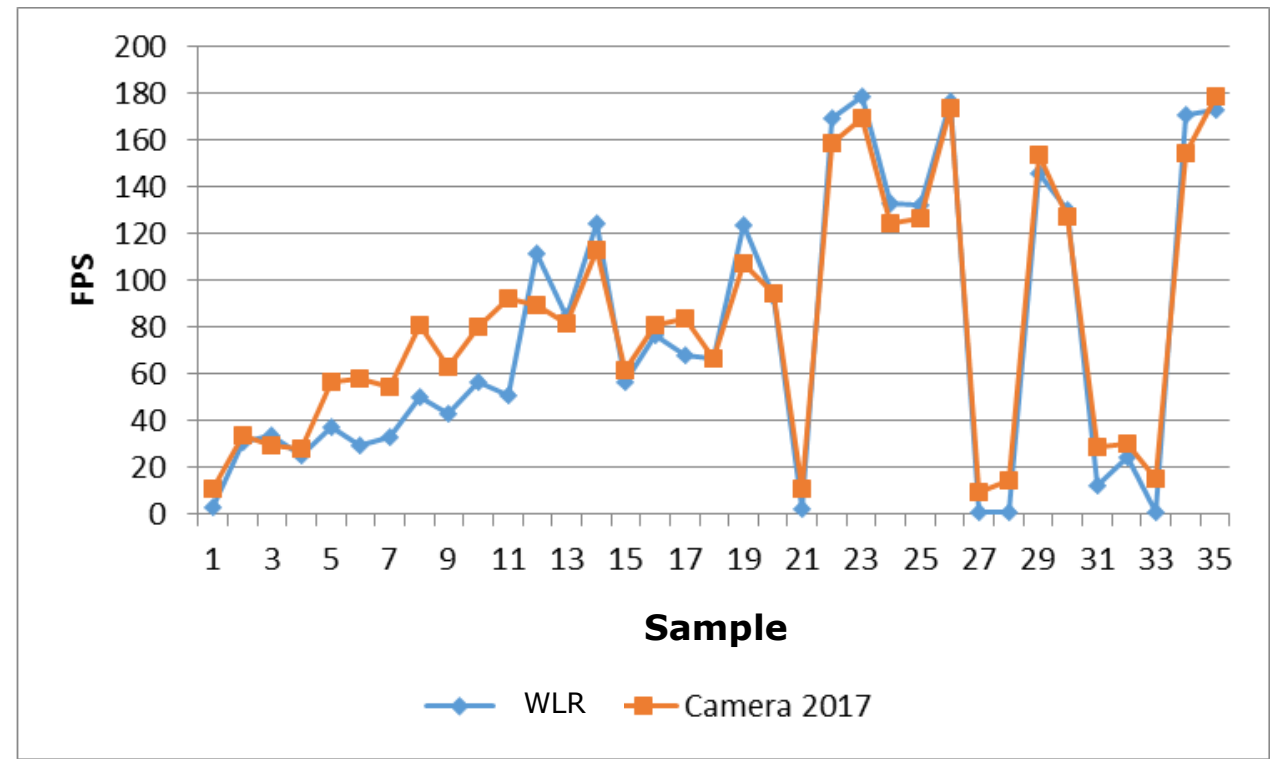

Figure B7.1 Graph of the differences in footpad lesion scores (FPS) per sample between the videoimaging system and the trained WLR inspector.

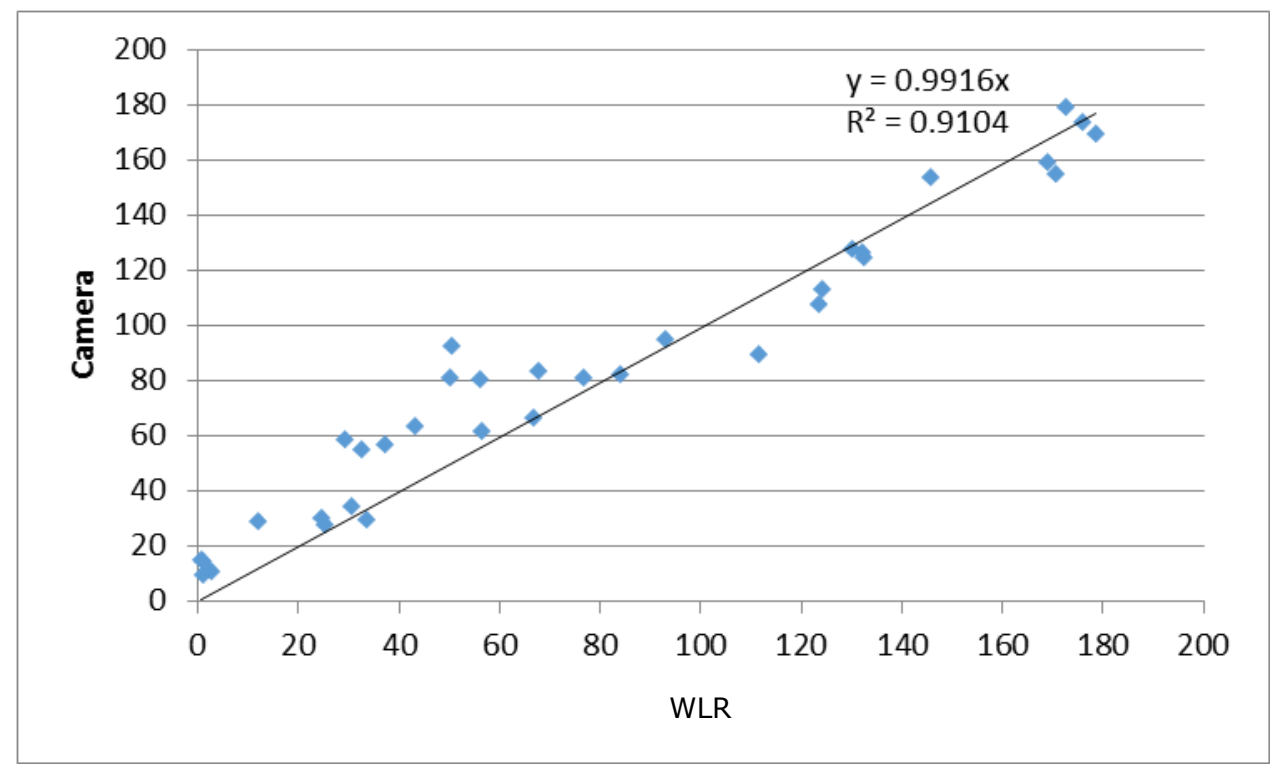

Figure B7.2 Relationship between the footpad lesion scores (FPS) per sample test given by the camera and the trained WLR inspector. The black line shows the situation in the case of $100 \%$ correlation between the camera and the WLR inspector. 


\section{Annex 8 Examples of images inaccurately measured}
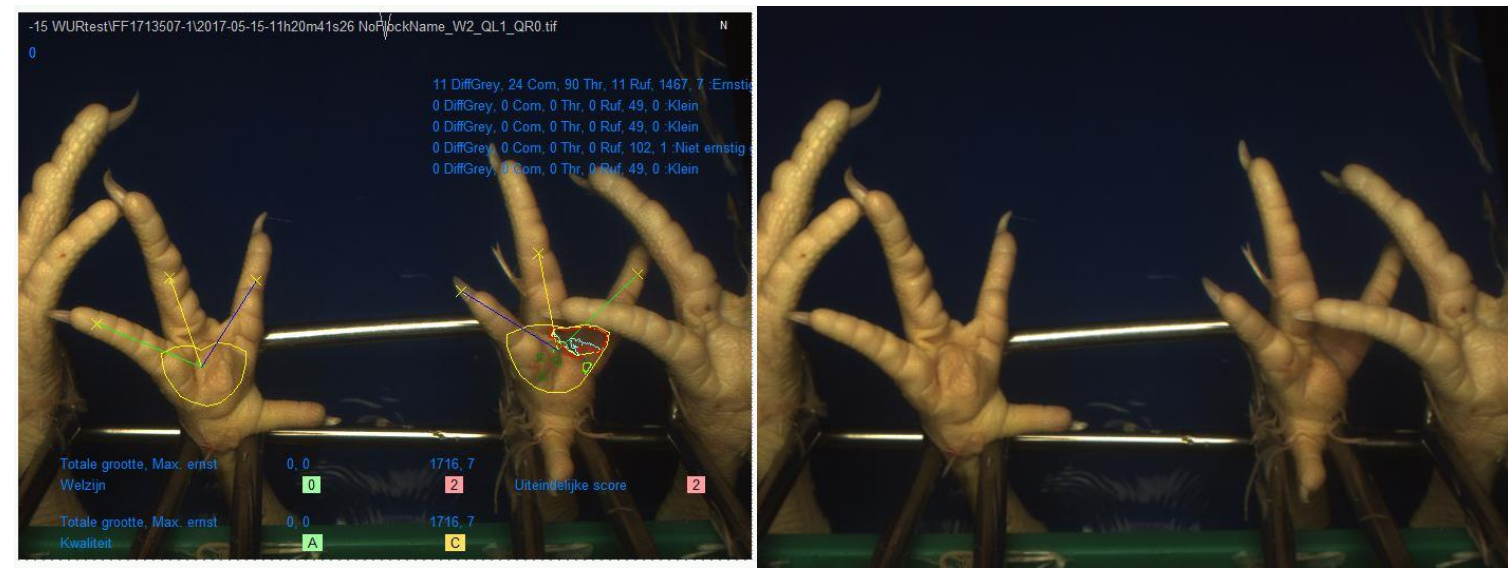

Foot of another chick
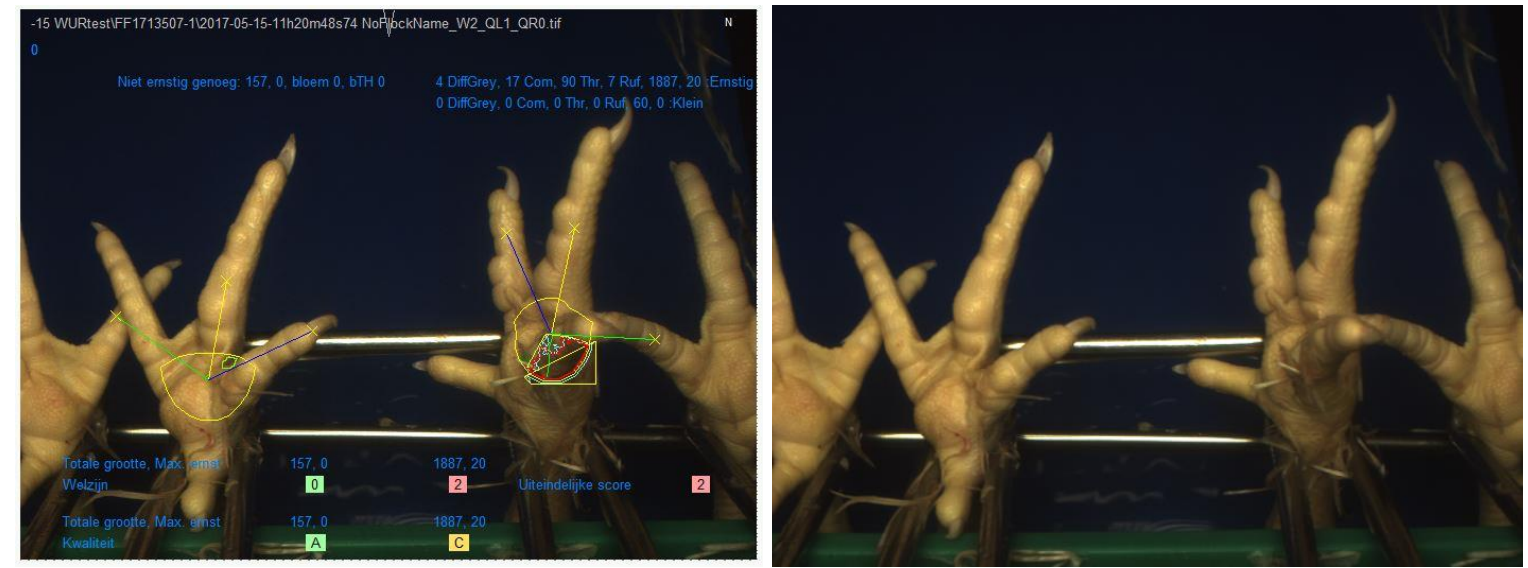

Turned foot + foot of another chick
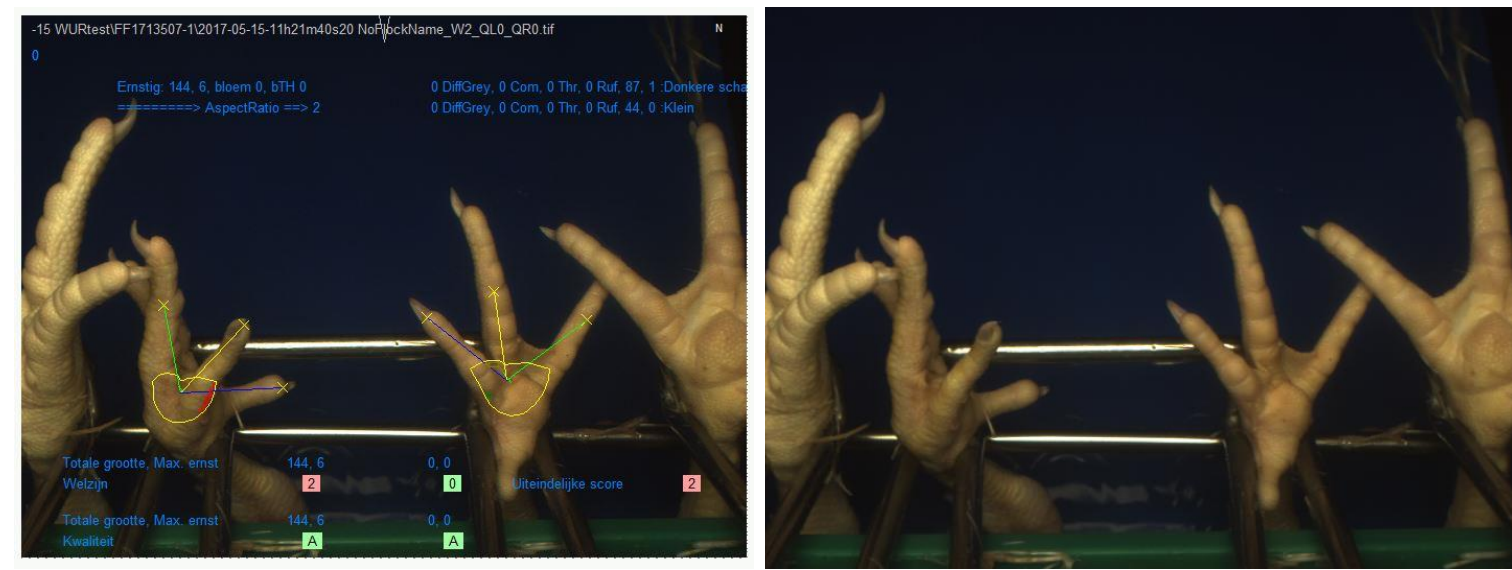

Turned foot 


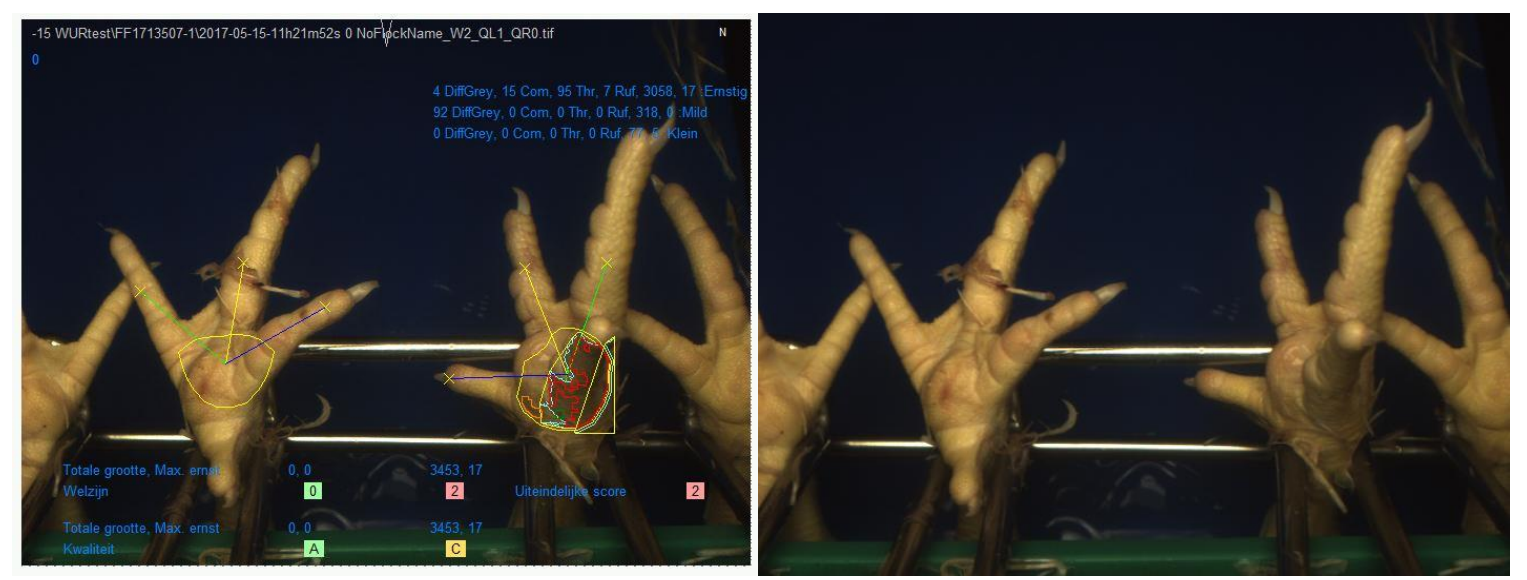

Turned foot, foot measured
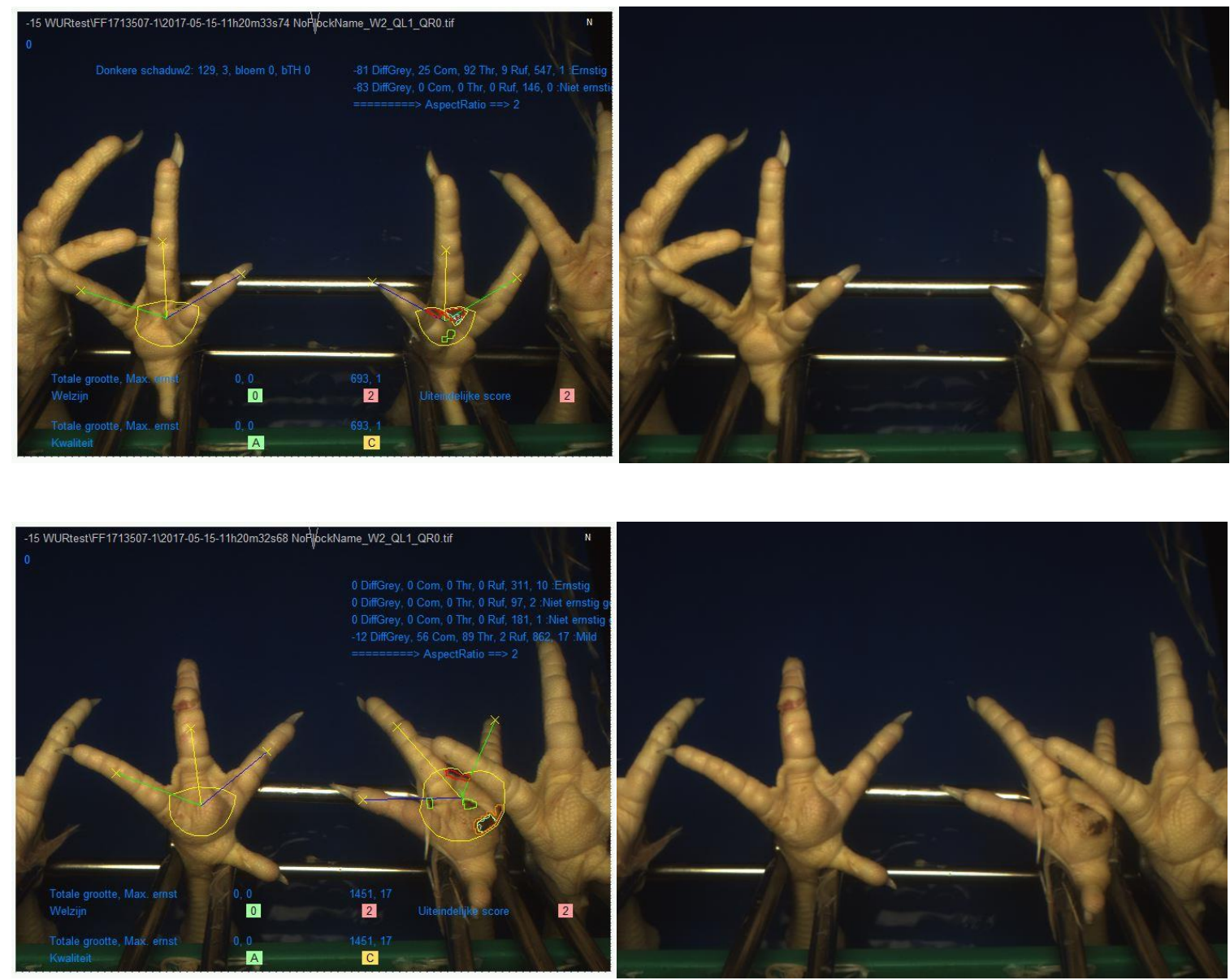


\section{Annex 9 Correlation per scoring class (based on samples)}

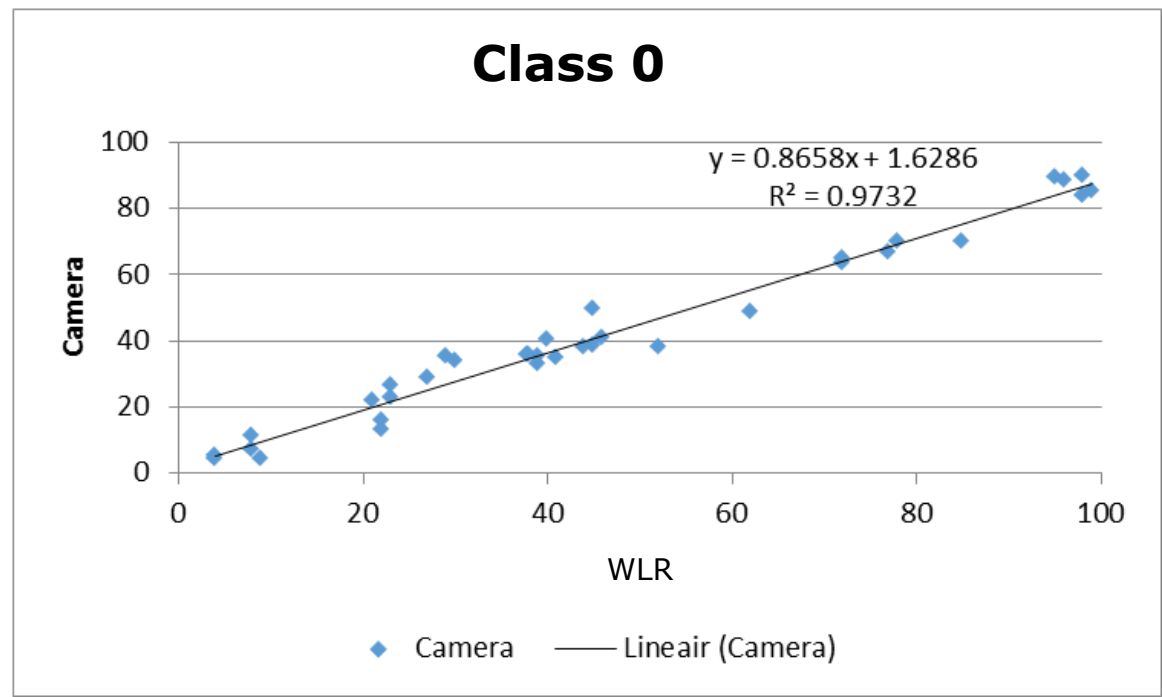

Figure B9.1 Correlation between camera and trained WLR inspector in class 0 (no lesion). The axes show the percentage of feet scored by WLR or the camera in class 0 (per sample test). The black line shows the situation in the case of $100 \%$ correlation between the camera and the WLR inspector.

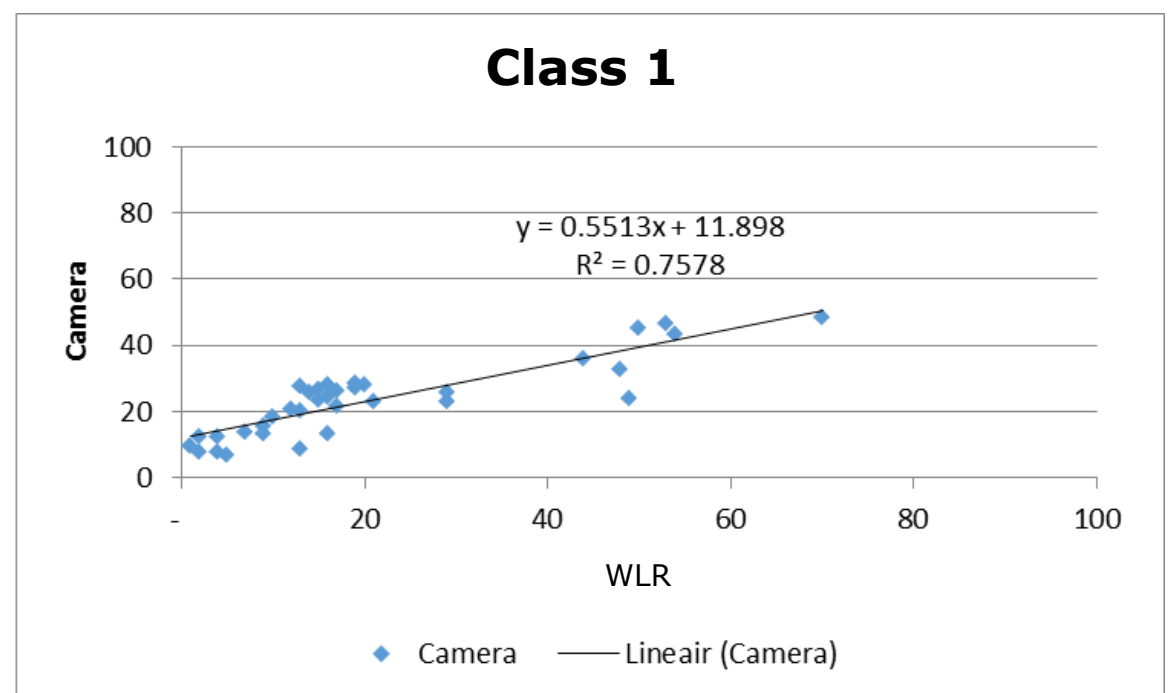

Figure B9.2 Correlation between camera and trained WLR inspector in class 1 (mild lesion). The axes show the percentage of feet scored by WLR or the camera in class 1 (per sample test). The black line shows the situation in the case of $100 \%$ correlation between the camera and the WLR inspector. 


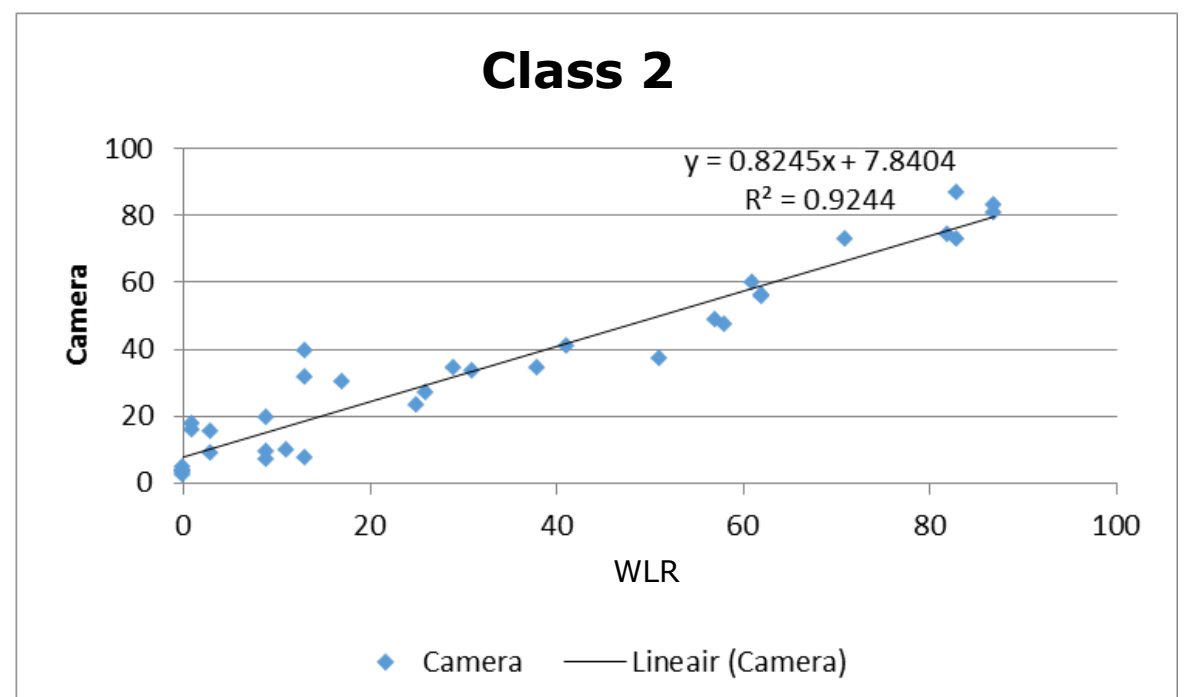

Figure B9.3 Correlation between camera and trained WLR inspector in class 2 (severe lesion). The axes show the percentage of feet scored by WLR or the camera in class 2 (per sample test). The black line shows the situation in the case of $100 \%$ correlation between the camera and the WLR inspector. 


\section{Annex 10 Correlation footpad lesion score (based on sample test)}

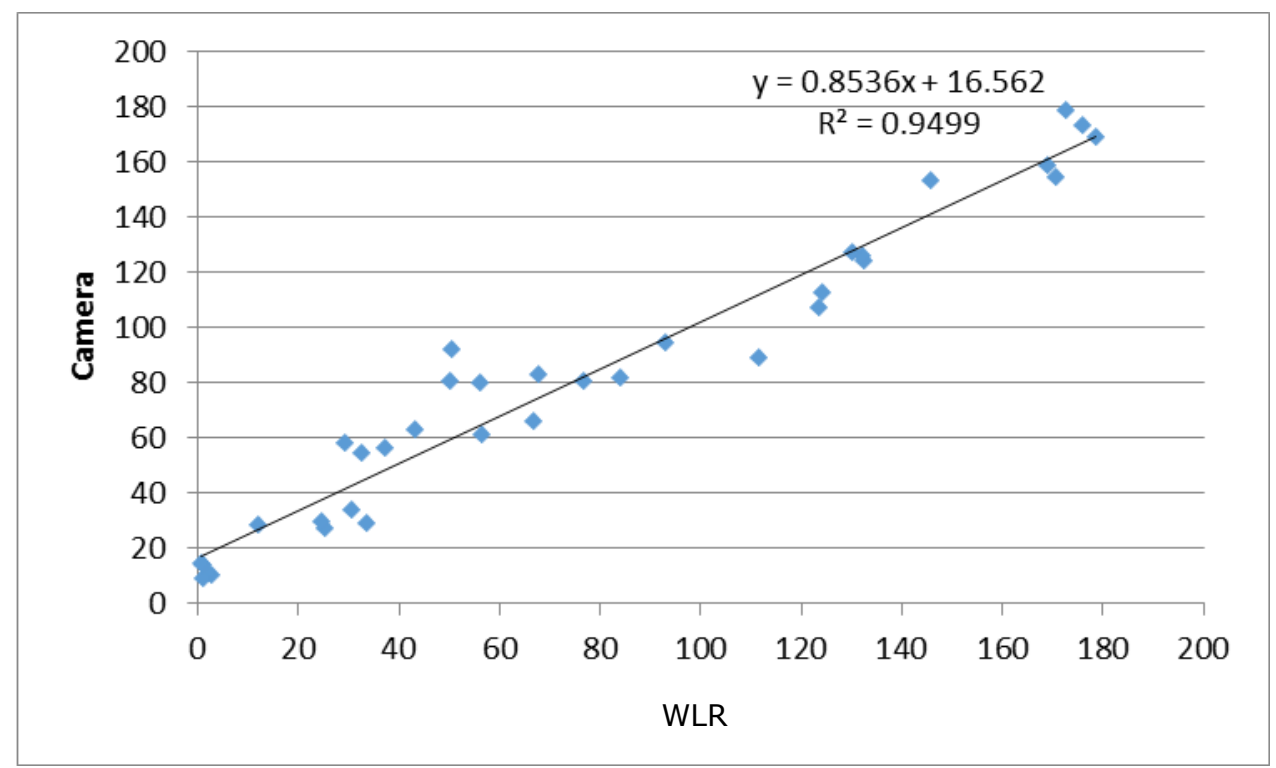

Figure B10.1 Relationship between the footpad lesion scores (FPS) per sample test given by the camera and the trained WLR inspector. The black line shows the situation in the case of $100 \%$ correlation between the camera and the WLR inspector. 


\section{Annex 11 Statistical analysis}

\section{Video-imaging system versus manual system}

Table B11.1 in this annex shows the estimated parameters of the regression line which ensue in bias (systematic difference from the video-imaging system). For the situation in soft scald, with a reference total score $=0$, there is an overestimation of 11.6. The intercept of the bias line as a result differs significantly from 0 . This overestimation appears ( $p$-value of the test for the difference with soft scald is 0.07$)$ to be greater with hard scald and is estimated at $17.3(11.6+5.7)$.

The bias is reduced to the extent that the reference score is greater than 0 . This is because the regression coefficient of the bias line has a value of 0.86 which is significantly smaller than 1 . Finally, this makes for a negative bias in relatively higher reference scores (from reference_total score 83 (soft scald) or 124 (hard scald).

Table B11.1: estimated parameters for the bias (systematic difference compared with the reference total score).

\begin{tabular}{|l|c|c|c|c|}
\hline Parameter & Estimate & Se & $\begin{array}{c}\text { Statistical test } \\
(\mathrm{H} 0)\end{array}$ & $\begin{array}{c}\text { P-value of } \\
\text { the test }\end{array}$ \\
\hline $\begin{array}{l}\text { Intercept soft } \\
\text { scald }\end{array}$ & 11.6 & 3.6 & $\beta_{0, i=1}=0$ & $<0.01$ \\
\hline $\begin{array}{l}\text { Difference in } \\
\text { intercept for hard } \\
\begin{array}{l}\text { scald (compared } \\
\text { with soft scald) }\end{array}\end{array}$ & 5.7 & 0.9 & $\Delta \beta_{0, i=2}=0$ & $<0.10$ \\
\hline $\begin{array}{l}\text { Regression } \\
\text { coefficient }\end{array}$ & 0.86 & 0.04 & $\beta_{1}=1$ & $<0.01$ \\
\hline
\end{tabular}

Figure B11.1 shows the regression line of the bias for both situations (soft scald and hard scald). The figures also show the $y=x$ line. The bias (systematic error) is the difference in the $y$ axis value between both lines. This difference therefore depends on the level of the reference score.

Figure 1 also shows the individual differences of the observations compared with the bias line. This shows an image of the (random) inaccuracy. It can be noted however that the camera score almost always differs positively around the reference score $=50$ and that here there is only information available on the soft scald method. However, these seven observations with a positive difference from the sample test in soft scald are observations from the same broiler house of origin (distributed over 2 flocks).

This gives us the impression that the random differences (inaccuracy) have a strong broiler-housedependent component. 


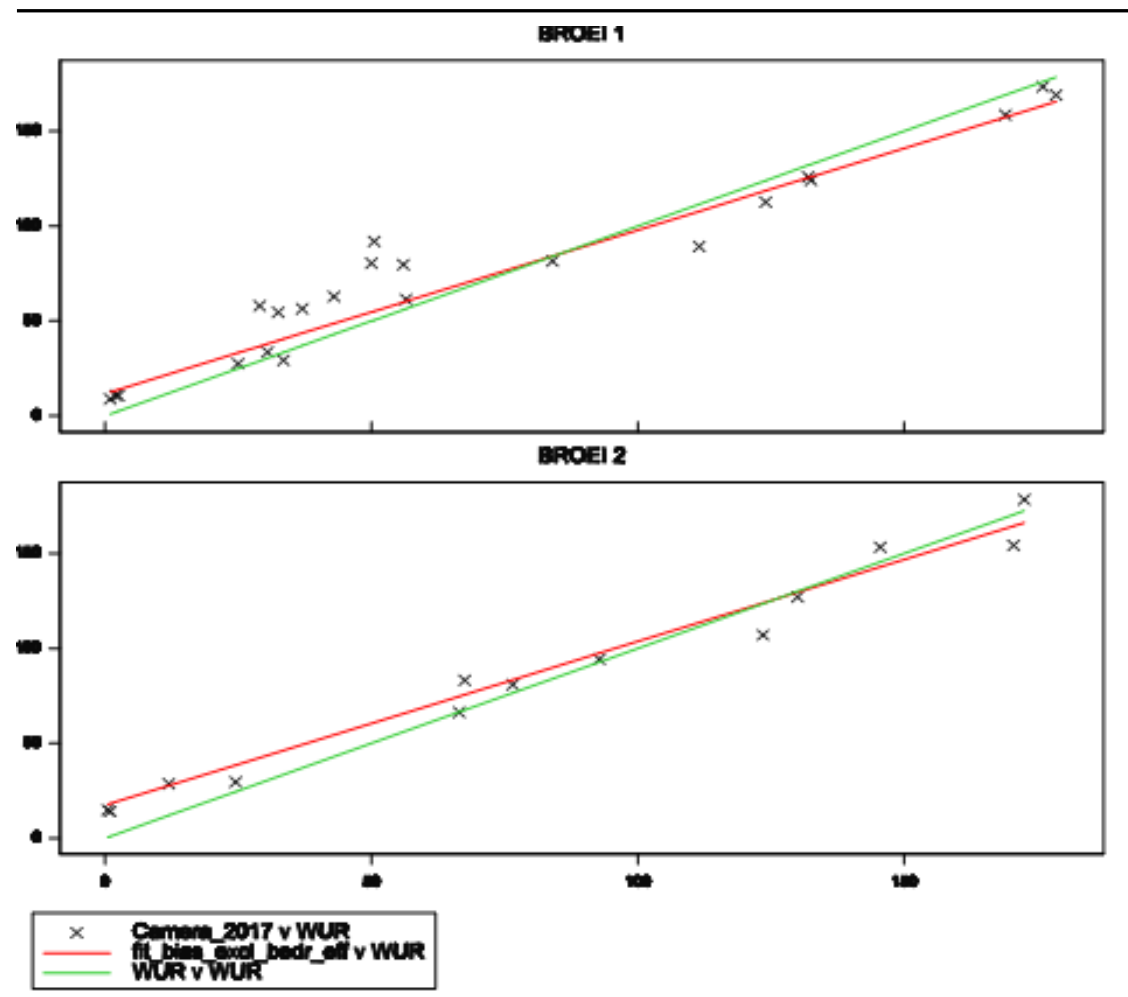

Figure B11.1: total score_camera (y-axis) versus total score_reference ( $x$-axis_per sample per scald type (scald 1 = soft scald; scald 2 = hard scald); individual observations (symbol $x$ ) and line $y=x$ (green) and the bias line (red)

Table B11.2: estimated parameters for additional inaccuracy (random difference with the reference total score).

\begin{tabular}{|l|c|c|c|}
\hline & range & Variance component $\left(\mathrm{s}^{2}\right)$ & $2 \mathrm{~s}$ \\
\hline $\begin{array}{l}\text { broiler chicken broiler } \\
\text { house effects }\end{array}$ & Total range & $65.4^{\mathbf{1}}$ & 16.2 \\
\hline $\begin{array}{l}\text { Broiler chicken flock } \\
\text { effects }\end{array}$ & Total range & $\mathrm{NA}$ & NA \\
\hline Broiler chicken sample & Reference score: & & \\
test effects & $\mathbf{0 - 9}$ & $0.6^{\mathrm{a}}$ & 1.5 \\
& $\mathbf{1 0 - 6 6}$ & $52.2^{\mathrm{b}}$ & 14.4 \\
& $\mathbf{6 7 - 1 3 2}$ & $62.8^{\mathrm{b}}$ & 15.8 \\
& $\mathbf{1 3 3 - 1 9 0}$ & $91.5^{\mathrm{b}}$ & 19.1 \\
& $\mathbf{1 9 1 - 2 0 0}$ & $*$ & $*$ \\
\hline
\end{tabular}

Table B11.2 shows the estimated inaccuracy, split into the broiler house effect $(2 s=16.2)$ and the remaining/sample test inaccuracies. The remaining/sample test inaccuracies are significantly lower with low reference scores. This is logical and follows from the nature of the score (the minimum lies at $0)$.

In the range between the reference total score 10 and 190, the remaining/sample test inaccuracy appears to be comparable and is overall estimated at an average of 16.5 (2s).

All in all, these results mean that we can make an estimate as to the range within which the additional inaccuracy of an individual sample lies.

On broiler houses of origin with a relatively high broiler-house effect (e.g. +16.2), an individual sample can therefore have an additional difference (to the bias) of +32.7 points.

Differences of this extent can also indeed be seen in the raw observations on 1 of the broiler houses of origin.

This limited validation elicits the conclusion that there are broiler-house-related differences in the camera's assessment. 


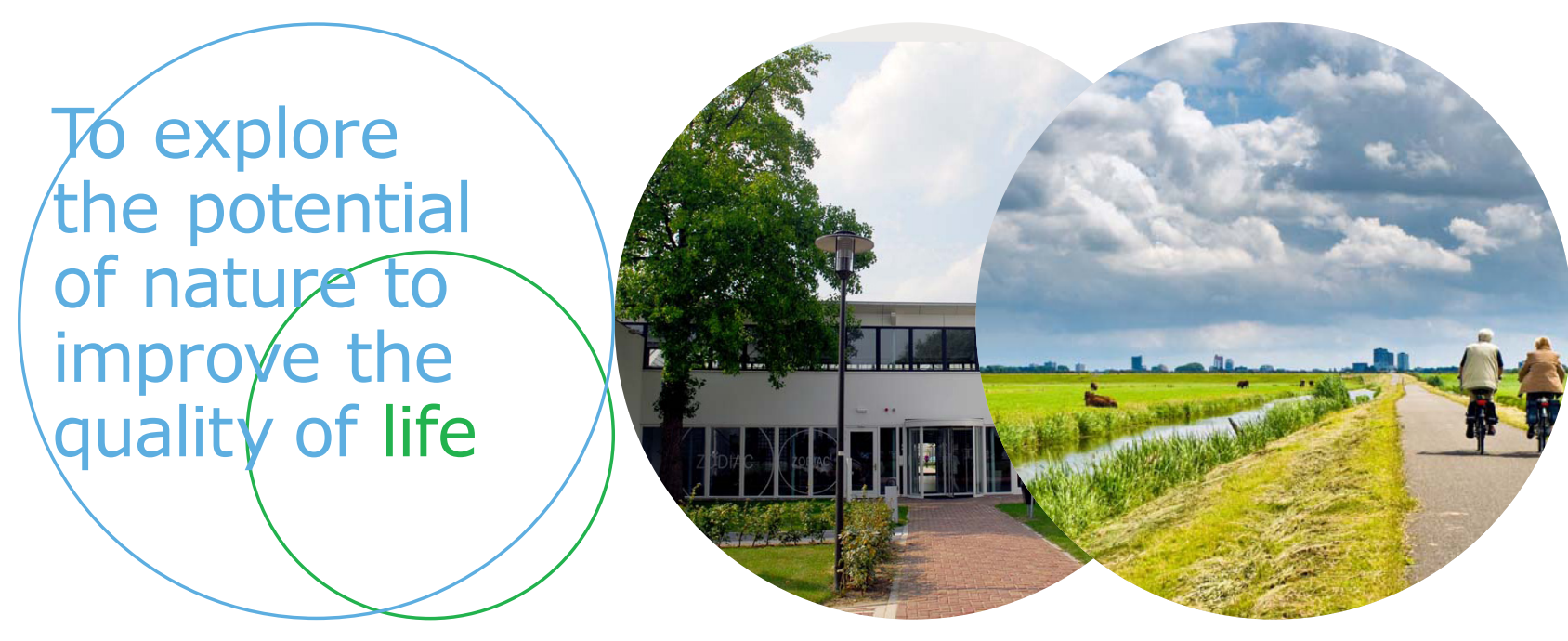

Wageningen Livestock Research P.O. Box 338

6700 AH Wageningen

The Netherlands

T +31 (0)317483953

E info.livestockresearch@wur.nl www.wur.nl/livestock-research

Wageningen Livestock Research creates science based solutions for a sustainable and profitable livestock sector. Together with our clients, we integrate scientific knowledge and practical experience to develop livestock concepts for future generations.

Wageningen Livestock Research is part of Wageningen University \& Research. Together we work on the mission: 'To explore the potential of nature to improve the quality of life'. A staff of 6,500 and 10,000 students from over 100 countries are working worldwide in the domain of healthy food and living environment for governments and the business community-at-large. The strength of Wageningen University \& Research lies in its ability to join the forces of specialised research institutes and the university. It also lies in the combined efforts of the various fields of natural and social sciences. This union of expertise leads to scientific breakthroughs that can quickly be put into practice and be incorporated into education. This is the Wageningen Approach. 